\title{
Functional Integration of Adult-Born Hippocampal Neurons after Traumatic Brain Injury
}

\author{
Laura E. Villasana, ${ }^{1}$ Kristine N. Kim, ${ }^{2}{ }^{\circledR}$ Gary L. Westbrook, ${ }^{3}$ and ${ }^{\circledR}$ Eric Schnell ${ }^{1,2}$ \\ DOI:http://dx.doi.org/10.1523/ENEURO.0056-15.2015 \\ ${ }^{1}$ Department of Anesthesiology and Perioperative Medicine, Oregon Health \& Science University, Portland, Oregon \\ 97239, ${ }^{2}$ VA Portland Health Care System, Portland, Oregon 97239, and ${ }^{3}$ The Vollum Institute, Oregon Health \& \\ Science University, Portland, Oregon 97239
}

\begin{abstract}
Traumatic brain injury (TBI) increases hippocampal neurogenesis, which may contribute to cognitive recovery after injury. However, it is unknown whether TBI-induced adult-born neurons mature normally and functionally integrate into the hippocampal network. We assessed the generation, morphology, and synaptic integration of new hippocampal neurons after a controlled cortical impact $(\mathrm{CCl})$ injury model of TBI. To label TBI-induced newborn neurons, we used 2-month-old POMC-EGFP mice, which transiently and specifically express EGFP in immature hippocampal neurons, and doublecortin-CreER ${ }^{T 2}$ transgenic mice crossed with Rosa26-CAGtdTomato reporter mice, to permanently pulse-label a cohort of adult-born hippocampal neurons. TBI increased the generation, outward migration, and dendritic complexity of neurons born during post-traumatic neurogenesis. Cells born after TBI had profound alterations in their dendritic structure, with increased dendritic branching proximal to the soma and widely splayed dendritic branches. These changes were apparent during early dendritic outgrowth and persisted as these cells matured. Whole-cell recordings from neurons generated during posttraumatic neurogenesis demonstrate that they are excitable and functionally integrate into the hippocampal circuit. However, despite their dramatic morphologic abnormalities, we found no differences in the rate of their electrophysiological maturation, or their overall degree of synaptic integration when compared to age-matched adult-born cells from sham mice. Our results suggest that cells born after TBI participate in information processing, and receive an apparently normal balance of excitatory and inhibitory inputs. However, TBI-induced changes in their anatomic localization and dendritic projection patterns could result in maladaptive network properties.
\end{abstract}

Key words: adult neurogenesis; functional integration; hippocampus; maturation; synaptic integration; traumatic brain injury

\section{Significance Statement}

Post-traumatic neurogenesis may contribute to recovery after traumatic brain injury (TBI), but the functional integrity of neurons generated after injury is critical and has not yet been examined. We used multiple lines of transgenic mice to label cells born after TBI in order to study their maturation and synaptic integration. Although cells born after TBI had significantly altered morphology and anatomic localization, they functionally integrated into the hippocampal circuit. Our data indicate that these adult-born neurons contribute to network connectivity after TBI, although changes in their morphology and dendritic projection patterns may alter their functional capacity. 


\section{Introduction}

In mammals, the generation of adult-born hippocampal neurons persists into late adulthood (van Praag et al., 2005; Zhao et al., 2008; Spalding et al., 2013) and is influenced by multiple environmental contingencies, such as learning (Gould et al., 1999), exposure to enriched environments (Kempermann et al., 1997), and exercise (van Praag et al., 1999). Hippocampal neurogenesis also increases in response to various neurological insults, including hypoxia (Zhu et al., 2005; Varela-Nallar et al., 2014), ischemia (Liu et al., 1998; Jin et al., 2001), seizures (Parent et al., 1997; Scharfman et al., 2000), and traumatic brain injury (TBI; Dash et al., 2001; Chirumamilla et al., 2002; Villasana et al., 2014). Because adult-born hippocampal neurons are important for learning and memory (Shors et al., 2001; Dupret et al., 2008; Sahay et al., 2011), post-traumatic hippocampal neurogenesis may compensate for functional deficits resulting from injury and contribute to cognitive recovery. To assay neurogenesis after $\mathrm{TBI}$, prior studies have focused on histochemical approaches in fixed tissue (Dash et al., 2001; Chirumamilla et al., 2002; Rice et al., 2003; Sun et al., 2007; Yu et al., 2008; Blaiss et al., 2011), which precludes functional analysis. Although the axons of granule cells born after TBI project to hippocampal region CA3 (Sun et al., 2007), it remains unknown whether these outputs are functional and, more importantly, whether these cells receive afferent input. Because mature granule cells in the dentate gyrus can be hyperexcitable after TBI (Santhakumar et al., 2000; Gupta et al., 2012), it is possible that cells born after TBI develop similar changes during their maturation.

Thus, to determine whether TBI alters the development and functional integration of adult-born hippocampal neurons, we used two lines of transgenic mice to assess early and late stages of the development and integration of adult-born neurons after a controlled cortical impact (CCl) model of TBI (Dash et al., 2001; Kernie et al., 2001). Proopiomelanocortin-enhanced green fluorescent protein (POMC-EGFP) transgenic mice transiently

Received May 21, 2015; accepted July 31, 2015; First published September 14, 2015.

The authors declare no competing financial interests.

Author Contributions: L.E.V., G.L.W., and E.S. designed research; L.E.V., K.N.K., and E.S. performed research; L.E.V. and E.S. analyzed data; L.E.V., G.L.W., and E.S. wrote the paper.

This work was funded by a Department of Veterans Affairs Career Development Award (VA BLR\&D CDA-2 005-10S; E.S.), a PVARF Summer Fellowship (K.N.K.), National Institutes of Health (NIH) Grant F32-NS083109 NRSA (L.E.V.), an Ellison Medical Foundation Award (G.L.W.), and NIH Grants R01NS080979 (GLW) and P30-NS061800 (Oregon Health \& Science University Imaging Center). We thank Drs. Zhi-Qi Xiong and Xuewen Cheng for providing Dcx-CreERT2 mice; and Dr. Stefanie Kaech-Petrie of the Oregon Health \& Science University Advanced Light Microscopy Core for assistance with imaging.

Correspondence should be addressed to Dr. Eric Schnell, VA Portland Health Care System, 3710 SW US Veterans Hospital Road, P3ANES, Portland, OR 97239. E-mail: schneler@ohsu.edu.

DOI:http://dx.doi.org/10.1523/ENEURO.0056-15.2015

Copyright (C) Villasana et al.

This is an open-access article distributed under the terms of the Creative Commons Attribution 4.0 International, which permits unrestricted use, distribution and reproduction in any medium provided that the original work is properly attributed. express GFP in adult-born neurons $~ 7-14$ d postmitosis, and were used to assess hippocampal neurogenesis at an early stage (Overstreet-Wadiche et al., 2006; Hunt et al., 2012; Villasana et al., 2014). We also used a novel line of transgenic mice, the doublecortin (Dcx)CreER $^{\mathrm{T} 2}$ line (Cheng et al., 2011), which, when crossed with a Rosa26-CAG-tdTomato (tdTom) reporter mouse (Madisen et al., 2010), allowed us to permanently and noninvasively pulse-label hippocampal granule cells born after TBI. Our results show that neurons born during post-traumatic neurogenesis survive and functionally integrate into hippocampal circuits, and show apparently normal synaptic properties despite markedly altered location and dendritic morphology.

\section{Material and Methods}

\section{Animals}

All procedures were performed according to the standards of the National Institutes of Health Guide for the Care and Use of Laboratory Animals and in compliance with approved institutional animal care protocols. Subjects were 2-month-old male and female heterozygotic POMC-EGFP mice (Overstreet et al., 2004) and Doublecortin-CreER ${ }^{\mathrm{T} 2}$ mice (generously provided by $\mathrm{Dr}$. Zhi-Qi Xiong, Institute of Neuroscience, Shanghai, China; Cheng et al., 2011) crossed with Rosa26-CAG-tdTomato marker mice (Madisen et al., 2010) and used as double heterozygotic transgenic mice. These complementary mouse lines allowed us to label neurons born during post-traumatic neurogenesis, and to examine them at both early and late time points. As these markers are expressed in vivo, this approach was used to analyze the physiological function of adult-born cells in acutely prepared brain slices as well as the morphology of adult-born cells in fixed tissue. Littermates were randomly allocated to either sham injury or $\mathrm{CCl}$ treatment. Prior to any quantification, the hippocampus was inspected, and any mice with damage to the dentate gyrus were excluded entirely ( $n=3$ total), and any slices with any damage to the Cornu Ammonis regions (CA1/CA3) of the hippocampus were discarded.

\section{Controlled cortical impact injury}

We used a $\mathrm{CCl}$ protocol to induce $\mathrm{TBI}$, as previously described (Kernie et al., 2001) with some modifications. Mice were anesthetized using spontaneously inhaled isoflurane (2\%) and mounted on a stereotaxic apparatus. A 4 $\mathrm{mm}$ craniotomy incision was made (dura intact) between lambda and bregma, bordered on the right of the midline. A $0.9 \mathrm{~mm}$ deformation $(4.4 \mathrm{~m} / \mathrm{s} ; 800 \mathrm{~ms}$ dwell) was made in the exposed cortical area using a 3-mm-diameter sterile stainless steel tip attached to an electromagnetic impactor (ImpactOne, Leica Microsystems). The scalp was then sutured, and mice recovered in a warm padded chamber. Sham mice received the same treatment (anesthetic, scalp incision/closure), with the exception of the craniotomy and impact. Each mouse was individually coded, and the experimenters were blinded for subsequent analyses. All mice survived $\mathrm{CCl}$. Mice were killed 2 
or 4 weeks after sham or $\mathrm{CCl}$ treatment for POMC-EGFP and DcxCre/tdTom mice, respectively.

\section{Bromodeoxyuridine injections}

Because dendritic development occurs rapidly in immature neurons and can be accelerated by neuronal injury (Overstreet-Wadiche et al., 2006; Niv et al., 2012), bromodeoxyuridine (BrdU) was used to date neurons in POMC-EGFP mice and to allow for comparison of agematched cells between treatment groups. BrdU (SigmaAldrich) was dissolved in warm sterile saline solution (10 $\mathrm{mg} / \mathrm{ml}$ ) and injected at $300 \mathrm{mg} / \mathrm{kg}$, i.p., twice a day for $2 \mathrm{~d}$ at 2, 5, or $7 \mathrm{~d}$ post-CCl (three separate cohorts). These mice were killed exactly 2 weeks after injury, such that the BrdU-labeled neurons were 12,9 , or $7 \mathrm{~d}$ postmitosis, respectively. The dendritic and somatic morphology of $\mathrm{BrdU}^{+}$cells was determined based on their GFP expression.

\section{Tamoxifen}

To pulse label newborn neurons in DcxCre/tdTom mice, mice received 2 daily intraperitoneal injections ( $7 \mathrm{~h}$ apart) of tamoxifen ( $40 \mathrm{mg} / \mathrm{kg}$ in corn oil) for $3 \mathrm{~d}$, starting $6 \mathrm{~d}$ after $\mathrm{CCl}$. Previous studies have confirmed that this regimen pulse labels hippocampal granule cells born 2-3 d prior to tamoxifen administration in DcxCreER ${ }^{\mathrm{T} 2} /$ marker mice (Cheng et al., 2011), which we confirmed using BrdU colabeling $(300 \mathrm{mg} / \mathrm{kg}$, i.p., two doses $4 \mathrm{~h}$ apart on a single day) and Dcx costaining. These mice provide a complementary approach to label adult-born neurons, for although immature neurons are efficiently labeled in POMC-EGFP mice, GFP expression is lost as they mature. In contrast, in DcxCre/tdTom mice, tdTom expression is permanent and can be used to analyze adult-born cells after they have matured. However, tdTom expression takes several days to become bright enough for detailed morphologic assessment of dendritic branching (see Fig. 4 below), and thus the POMC-EGFP animal was used for analysis at early time points.

\section{Immunohistochemistry}

Mice were terminally anesthetized according to institutional animal care and use committee-approved protocols, transcardially perfused with $4 \%$ paraformaldehyde in PBS, and post-fixed overnight. Free-floating coronal sections (150 $\mu \mathrm{m}$ thick) were prepared from each mouse and permeabilized in $0.4 \%$ Triton in PBS (PBST) for 45 min. Four sections containing the hippocampus (two dorsal: approximately -1.46 and $-2.18 \mathrm{~mm}$ from bregma; and two ventral: approximately -2.54 and $-2.80 \mathrm{~mm}$ from bregma) from each mouse were then blocked for 30 min with $10 \%$ horse serum in PBST and incubated overnight $\left(4^{\circ} \mathrm{C}\right)$ with primary antibody in $1.5 \%$ horse serum/ PBST. The primary antibodies were rabbit anti-GFP (Alexa Fluor 488 conjugated; 1:400; Invitrogen), rat anti-BrdU (1:500; Abcam), and guinea pig anti-Dcx (1:500; Millipore). Sections incubated with anti-BrdU were first incubated in $2 \mathrm{~N}$ hydrochloric acid in potassium-PBST for $30 \mathrm{~min}$ $\left(37^{\circ} \mathrm{C}\right)$, washed twice, and blocked with horse serum, as described above. The BrdU-stained samples were washed in PBST $(2 \times 10 \mathrm{~min})$ the following day and incu- bated with goat anti-rat (1:400; Rhodamine Red 568, Jackson Laboratories), donkey anti-rat (1:400; Alexa Fluor 488 , Invitrogen), or goat anti-guinea pig (1:400; Alexa Fluor 488, Invitrogen) for $2 \mathrm{~h}$ at room temperature. The sections were then washed in PBST $(2 \times 10 \mathrm{~min})$ and mounted with DAPI Fluoromount-G (SouthernBiotech) on coded slides.

\section{Confocal microscopy}

Four separate stained slices from the hippocampus of each mouse were imaged with a Zeiss LSM780 confocal microscope using a $10 \times / 0.45$ numerical aperture (NA) or $20 \times / 0.8$ NA lens. Images were kept coded and subsequently quantified using ImageJ software by an investigator blinded to experimental condition. For POMC-EGFP animals, all GFP ${ }^{+}$cells in a $10 \mu \mathrm{m} z$-stack within the middle region of the suprapyramidal blade of the dentate gyrus granule cell layer (GCL), including the subgranular zone (SGZ), were counted and normalized to the imaged GCL volume for each slice ipsilateral and contralateral to injury or sham. In DcxCre/tdTom mice, tdTomato ${ }^{+}$cells were quantified through the GCL of the entire span of the dentate gyrus/section in a $40-\mu \mathrm{m}$-thick $z$-stack and normalized to GCL volume. A greater sample volume was used to quantify adult-born cell density in DcxCre/tdTom mice than in POMC-EGFP mice because of the lower density of labeled cells in these animals. GCL volume was obtained by multiplying the area of the GCL within the quantified span by its depth (distance along the $z$-axis). The dorsal/ventral regions of hippocampus collected for the DcxCre/tdTom mice were similar to those for POMC-EGFP mice, and were kept constant between sham and $\mathrm{CCl}$ animals.

To assess cell migration, the distance from the center of each cell body to the SGZ/hilus border was measured for all cells in the middle section of the suprapyramidal blade of the dentate gyrus, as this was representative of the migration of cells throughout the dentate. Ectopic hilar or molecular layer migration was defined as the migrated cell lying outside of the GCL, $>10 \mu \mathrm{m}$ away from the inner border of the SGZ or the outer border of the GCL, respectively. Dendritic tree morphology was obtained by identifying cell bodies in the middle (z-direction) of a tissue section, imaging them in their entire $z$-axis using a confocal stack, and tracing them off-line using ImageJ. Cells with dendrites truncated by sectioning were not included. Group data were obtained from five to eight cells from each animal using the ImageJ Sholl analysis plug-in [Ghosh laboratory (http://labs.biology.ucsd.edu/ghosh/ software/)]. ImageJ was also used to measure the distance between the soma and the first branch point, the angle between the two farthest dendrites with the vertex at the first apical dendritic branch, and the area contained within the space bordered by the two farthest dendrites seen on the projected image and the edge of the outer molecular layer (OML). Total dendritic distance was calculated as the sum of the length of all dendrites for each cell. tdTom ${ }^{+}$cells were also categorized based on their morphology into the following four major classes: (1) typical (one apical dendrite directed toward the molecular layer with its first-order branch $>10 \mu \mathrm{m}$ from its cell 
body); (2) cells with more than one apical dendrite; (3) cells with dendrites that branched proximal to their cell body $(<10 \mu \mathrm{m})$; and (4) cells with laterally projecting apical dendrites $\left(<30^{\circ}\right.$ from the long axis of the GCL).

Spine density was assessed in the inner molecular layer (IML) and OML of the dentate for adult-born cells for POMC-EGFP and DcxCre/tdTom mice, respectively, using images of dendritic segments obtained using a $40 \times /$ 1.4 NA lens from three to five different cells for each animal. For any given tdTom ${ }^{+}$cell, spine densities in the inner and middle layers appeared similar to the density in the OML, and were not quantified. For all analyses of sham versus $\mathrm{CCl}$-treated mice as well as ipsilateral and contralateral samples, matching regions of the suprapyramidal blade (middle portion) of the dentate gyrus were used. Sections were also matched on their anteroposterior axis between animals.

\section{Electrophysiology}

Acute hippocampal slices were prepared from mice 2 weeks (POMC-EGFP mice) or 1 month (DcxCre/tdTom mice) after sham or $\mathrm{CCl}$ treatment. After deep isoflurane anesthesia, mice received a terminal dose of avertin followed by transcardiac perfusion using an ice-cold choline chloride-based solution. The $300 \mu \mathrm{m}$ transverse hippocampal slices were cut on a Leica 1200 S Vibratome from the hemisphere ipsilateral to the injury/sham treatment, and were allowed to recover in ACSF containing 1.3 $\mathrm{mm}$ sodium ascorbate at $34^{\circ} \mathrm{C}$ for $30 \mathrm{~min}$ before transfer to room temperature. The external solution (ACSF) contained the following (in mM): $125 \mathrm{NaCl}, 25 \mathrm{NaHCO}_{3}, 2.5$ $\mathrm{KCl}, 1.25 \mathrm{NaH}_{2} \mathrm{PO}_{4}, 2.0 \mathrm{CaCl}_{2}, 1.0 \mathrm{MgCl}_{2}$, and 25 D-glucose, bubbled with $95 \% \mathrm{O}_{2}-5 \% \mathrm{CO}_{2}$. Individual fluorescent (adult-born) granule cells were identified using combined fluorescence/differential interference contrast imaging. Cells were patched using 3-4 $\mathrm{M} \Omega$ leaded glass pipettes (WPI), which allowed us to form seals with resistances of $>50 \mathrm{G} \Omega$. For single-cell voltage-clamp recordings, the cesium-gluconate-based internal solution contained the following (in $\mathrm{mM}$ ): 100 gluconic acid, 10 EGTA, 10 HEPES, $17.5 \mathrm{CsCl}, 8 \mathrm{NaCl}, 2 \mathrm{Mg}$-ATP, and 0.3 Na-GTP, pH 7.3 (using 50\% CsOH), 290 mOsm. Signals were obtained using an Axopatch 200B amplifier, filtered at $5 \mathrm{kHz}$, and sampled at $10 \mathrm{kHz}$ using IGOR Pro software (WaveMetrics) and a NIDAQ A/D board. Passive cell membrane properties and series resistances were monitored on-line using a $-10 \mathrm{mV}$ test pulse. Series resistances ranged from 6 to $20 \mathrm{M} \Omega$ and were not significantly different between groups in any experiments.

Synaptic responses were evoked using a bipolar stimulating electrode (FHC Inc.) placed at the middle molecular layer (MML)/OML border (for DcxCre/tdTom cells) or at the IML/MML border (POMC-EGFP cells) $\sim 100 \mu \mathrm{m}$ away from the cell. IPSCs were measured while clamping the granule cell at the verified reversal potential for glutamatergic currents $(0 \mathrm{mV})$ in the absence of receptor antagonists. AMPAR- and NMDAR-mediated currents were obtained by recording from cells at -70 and $+40 \mathrm{mV}$ in the presence of the $\mathrm{GABA}_{A}$ receptor $\left(\mathrm{GABA}_{A} \mathrm{R}\right)$ antagonist SR95531 $(10 \mu \mathrm{M})$, and the relative NMDAR-mediated cur- rent was measured as the amplitude of the combined EPSC measured at $+40 \mathrm{mV}$ at a latency of $60 \mathrm{~ms}$ after stimulation, at which point the AMPAR-mediated current had completely decayed. sEPSCs and mEPSCs were recorded at $-70 \mathrm{mV}$ in SR95531 for a minimum of $5 \mathrm{~min}$ of continuous recording (per cell) in the absence or presence of TTX, respectively. Events were automatically detected using a rise time-based algorithm with custom-written software in IGOR Pro software, with a threshold amplitude set at $4 \mathrm{pA}$, followed by manual checking of each event.

Whole-cell current-clamp recordings were performed using a potassium gluconate-based internal solution containing the following (in mM): KGluconate $130, \mathrm{KCl} 20$, HEPES 10, EGTA 0.1, Mg-ATP 4, and Na-GTP 0.3, pH 7.2. Cells were patched in voltage-clamp mode, and resting membrane potential was determined as the membrane voltage measured in tracking (current $=0$ ) mode immediately after break-in. The junction potential was $-8 \mathrm{mV}$ and was uncorrected. Passive cell membrane properties were determined using a $-10 \mathrm{mV}$ voltage step in voltage-clamp mode prior to experiments. In current clamp, small amounts of negative current were injected (1-2 pA) if needed to bring all cells to equivalent $V_{\mathrm{m}}=-80 \mathrm{mV}$ for current step experiments. Voltage changes were recorded in response to $2 \mathrm{~s}$ current steps of -10 to $+50 \mathrm{pA}$ for POMC-EGFP cells, and from -10 to $+200 \mathrm{pA}$ for tdTom ${ }^{+}$cells.\& Spike amplitude, width, rise slope, and threshold were measured from single traces using IGOR Pro software.

\section{Statistics}

For all statistical analyses, data were first assessed for normality and homogeneity of variance to determine the use of parametric or nonparametric tests, as indicated in the Results section. Data are expressed as the mean \pm SEM. Statistical analyses were conducted using SPSS Statistics (IBM), and group comparisons were considered significant at $p<0.05$. All figures were generated using Prism Software (GraphPad Software) or IGOR Pro (WaveMetrics). Table 1 lists the tests used and the retrospective power calculation for each reported statistical measurement.

\section{Results}

$\mathrm{CCl}$ increases the generation and outward migration of immature newborn neurons early after injury

We used a $\mathrm{CCl}$ model of TBI in mice (Fig. $1 A$ ) to follow the early development of neurons born after injury. We used POMC-EGFP mice because they specifically and transiently express GFP in immature (7- to 14-d-old) hippocampal adult-born neurons, providing both quantitative and qualitative assessments of neurogenesis (Overstreet et al., 2004). Mice were analyzed 2 weeks after injury, so that GFP-positive cells were those generated during the first few days after $\mathrm{CCl}$.

In accordance with prior observations (Dash et al., 2001; Kernie et al., 2001), CCl increased the number of immature adult-born neurons (GFP ${ }^{+}$cells) in region-matched sections of dentate gyrus $\left(F_{(1,26)}=12.09 ; p=0.002^{1} ; n=\right.$ 7, 8 mice per group; Fig. $1 B, D)$. Although the effect was more pronounced in the ipsilateral hemisphere, there was 
Table 1: Statistical table

\begin{tabular}{|c|c|c|c|}
\hline & Data structure & Type of test & Power \\
\hline 1 & Normal distribution & Two-way ANOVA & 0.94 \\
\hline 2 & Normal distribution & Two-way ANOVA & 0.24 \\
\hline 3 & Normal distribution & Two-tailed $t$ test & 0.87 \\
\hline 4 & Normal distribution & Two-way ANOVA & 0.03 \\
\hline 5 & Non-normal distribution & Kruskal-Wallis & 0.97 \\
\hline 6 & Non-normal distribution & Dunn's post hoc & 0.60 \\
\hline 7 & Non-normal distribution & Dunn's post hoc & 0.50 \\
\hline 8 & Normal distribution & Fisher's LSD & 0.91 \\
\hline 9 & Normal distribution & Two-way ANOVA & 0.96 \\
\hline 10 & Normal distribution & Two-way ANOVA & 0.44 \\
\hline 11 & Non-normal distribution & Mann-Whitney $U$ test & 0.84 \\
\hline 12 & Non-normal distribution & Mann-Whitney $U$ test & 0.12 \\
\hline 13 & Normal distribution & Three-way repeated-measures ANOVA & 0.32 \\
\hline 14 & Normal distribution & Fisher's LSD & $\begin{array}{l}0.27,0.78,0.94,0.97,0.34,0.03,0.08,0.11,0.08 \text {, and } \\
\quad 0.04 \text { for each branch point }\end{array}$ \\
\hline 15 & Normal distribution & Three-way repeated-measures ANOVA & 0.56 \\
\hline 16 & Normal distribution & Two-tailed $t$ test & 0.90 \\
\hline 17 & Normal distribution & Two-tailed $t$ test & 0.94 \\
\hline 18 & Normal distribution & Two-tailed $t$ test & 0.91 \\
\hline 19 & Normal distribution & Two-tailed $t$ test & 0.08 \\
\hline 20 & Normal distribution & Two-tailed $t$ test & 0.12 \\
\hline 21 & Normal distribution & Two-tailed $t$ test & 0.31 \\
\hline 22 & Normal distribution & Two-tailed $t$ test & 0.04 \\
\hline 23 & Normal distribution & Two-tailed $t$ test & 0.12 \\
\hline 24 & Normal distribution & Two-tailed $t$ test & 0.16 \\
\hline 25 & Normal distribution & Two-tailed $t$ test & 0.22 \\
\hline 26 & Normal distribution & Two-tailed $t$ test & 0.69 \\
\hline 27 & Normal distribution & Two-tailed $t$ test & 0.16 \\
\hline 28 & Normal distribution & Two-tailed $t$ test & 0.19 \\
\hline 29 & Non-normal distribution & Mann-Whitney $U$ test & 0.74 \\
\hline 30 & Non-normal distribution & Mann-Whitney $U$ test & 0.54 \\
\hline 31 & Non-normal distribution & Mann-Whitney $U$ test & 0.72 \\
\hline 32 & Normal distribution & Two-way repeated-measures ANOVA & 0.99 \\
\hline 33 & Normal distribution & Two-way repeated-measures ANOVA & 0.47 \\
\hline 34 & Normal distribution & Fisher's LSD & $\begin{array}{l}0.95,0.87,0.85,0.86 \text {, and } 0.51 \text { for branch points } \\
\text { between } 10 \text { and } 50 \mu \mathrm{m} \text { from the soma; } 0.55,0.90 \text {, } \\
0.94,0.76,0.86,0.86,0.85 \text {, and } 0.55 \text { for branch points } \\
\text { between } 150 \text { and } 220 \mu \mathrm{m} \text { from the soma }\end{array}$ \\
\hline 35 & Normal distribution & Two-tailed $t$ test & 0.97 \\
\hline 36 & Normal distribution & Two-tailed $t$ test & 0.92 \\
\hline 37 & Normal distribution & Two-tailed $t$ test & 0.54 \\
\hline 38 & Non-normal distribution & Mann-Whitney $U$ test & 0.64 \\
\hline 39 & Normal distribution & Two-tailed $t$ test & 0.09 \\
\hline 40 & Normal distribution & Two-tailed $t$ test & 0.06 \\
\hline 41 & Normal distribution & Two-tailed $t$ test & 0.03 \\
\hline 42 & Normal distribution & Two-tailed $t$ test & 0.04 \\
\hline 43 & Normal distribution & Two-tailed $t$ test & 0.06 \\
\hline 44 & Normal distribution & Two-tailed $t$ test & 0.06 \\
\hline 45 & Normal distribution & Two-tailed $t$ test & 0.05 \\
\hline 46 & Normal distribution & Two-tailed $t$ test & 0.22 \\
\hline 47 & Normal distribution & Two-tailed $t$ test & 0.27 \\
\hline 48 & Normal distribution & Two-tailed $t$ test & 0.04 \\
\hline 49 & Normal distribution & Two-tailed $t$ test & 0.06 \\
\hline 50 & Normal distribution & Two-tailed $t$ test & 0.12 \\
\hline 51 & Normal distribution & Two-tailed $t$ test & 0.05 \\
\hline 52 & Normal distribution & Two-tailed $t$ test & 0.04 and 0.06 for PPF 50, 100, and $250 \mathrm{~ms}$ \\
\hline 53 & Normal distribution & Two-tailed $t$ test & 0.08 \\
\hline 54 & Normal distribution & Two-tailed $t$ test & 0.07 \\
\hline 55 & Normal distribution & Two-tailed $t$ test & 0.05 \\
\hline 56 & Normal distribution & Two-tailed $t$ test & 0.10 \\
\hline
\end{tabular}

PPF, Paired-pulse facilitation. 

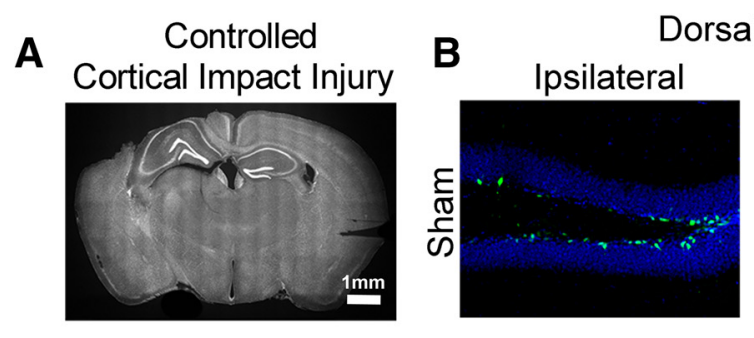

Dorsal Hipp
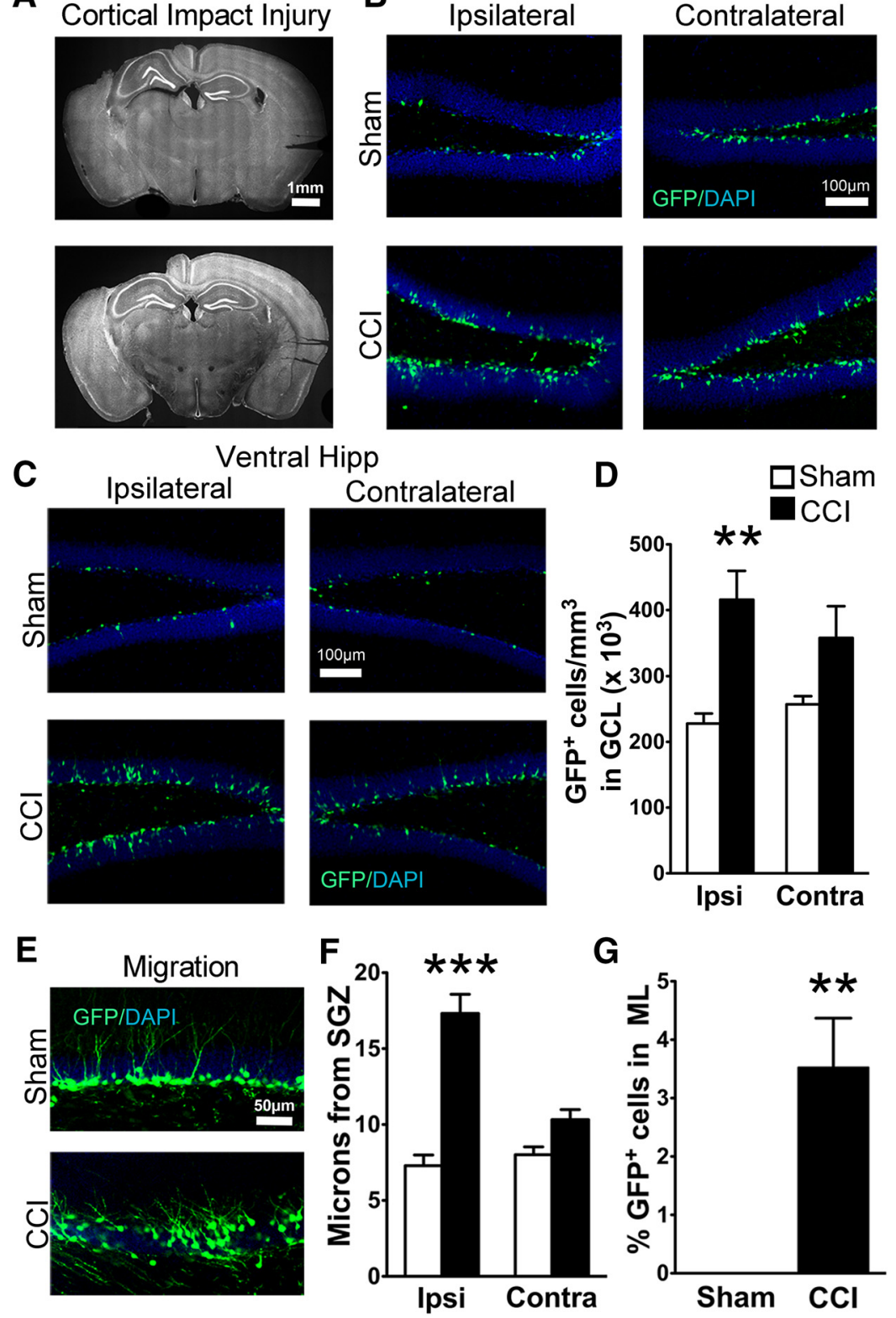

Figure 1. Transgenic POMC-EGFP mice demonstrate CCl-induced neurogenesis and increased dispersion of immature granule cells. $\boldsymbol{A}$, Representative images of the extent of cortical damage 2 weeks following $\mathrm{CCl}$. The noninjured (contralateral) sides are marked by notches in the cortical tissue placed during processing. $\boldsymbol{B}, \boldsymbol{C}$, Representative images of GFP ${ }^{+}$cells in the dorsal $(\boldsymbol{B})$ and ventral $(\boldsymbol{C})$ hippocampus of sham and CCl-treated mice 2 weeks after surgery, both ipsilateral and contralateral to injury. $\boldsymbol{D}, \mathrm{CCl}$-treated mice had more GFP ${ }^{+}$cells on the injured hemisphere compared to sham mice ( $* * p=0.0001^{3}, n=7$ and 8 mice/group). $\boldsymbol{E}$, Representative images of $\mathrm{GFP}^{+}$cell dispersion in the granule cell layer of the ipsilateral dentate gyrus. $\boldsymbol{F}$, CCl-treated mice had increased cell migration away from the SGZ on the injured hemisphere compared with sham mice (***p $=0.0001^{8}, n=6$ mice/group; white and black bars represent sham and $\mathrm{CCl}$-treated mice, respectively). $\mathbf{G}, \mathrm{A}$ greater percentage of $\mathrm{GFP}^{+}$cells from CCl-treated mice migrated into the molecular layer (ML) of the ipsilateral dentate gyrus $\left(* * p=0.0028^{11}, n=6\right.$ mice/group).

no significant hemisphere $\times$ injury interaction $\left(p=0.26^{2}\right)$. However, when comparing hemispheres separately between sham and CCl-treated mice using two-tailed $t$ tests, a significant difference was observed only on the injured side $\left(p=0.0001^{3}\right)$. Therefore, further analyses focused on the ipsilateral hemisphere. As $\mathrm{CCl}$ occasionally caused morphologic distortion of the dorsal dentate gyrus near the injury (Fig. 1A, top), we also analyzed cell density in the ventral hippocampus, which did not have any morphologic alterations. The $\mathrm{CCl}$-induced increase in $\mathrm{GFP}^{+}$cell density was observed throughout the ipsilateral dentate gyrus, as there was no significant interaction between hippocampal region (dorsal vs ventral) and treatment $\left(p=0.83^{4} ;\right.$ Fig. $\left.1 B, C\right)$. To determine whether the 
increase in neurogenesis was influenced by sex, we compared the densities of immature adult-born neurons in male and female mice. The overall effect of $\mathrm{CCl}$ on the number of adult-born neurons $\left(p=0.0001^{5}\right)$ was significant in both female $\left(p=0.027^{6}\right)$ and male mice $(p=$ $0.049^{7}$; female sham injury mice: $238 \pm 21 \mathrm{cells} / \mathrm{mm}^{3}, n=$ 3; female CCl injury mice: $497 \pm 15$ cells $/ \mathrm{mm}^{3}, n=3$; male sham injury mice: $204 \pm 22$ cells $/ \mathrm{mm}^{3}, n=4$; male $\mathrm{CCl}$ injury mice: $331 \pm 30 \mathrm{cells} / \mathrm{mm}^{3}, n=5$ ).

As adult-born hippocampal granule cells mature and integrate into the hippocampus, they migrate from the subgranular zone toward the molecular layer (Cameron et al., 1993), and this migration can be accelerated by injuries such as seizures (Overstreet-Wadiche et al., 2006). Similar to closed head injury (Villasana et al., 2014), $\mathrm{CCl}$ caused a dramatic increase in the outward migration of $\mathrm{GFP}^{+}$neurons born after injury specifically in the injured hemisphere $\left(p=0.0001^{8}\right.$ in the injured hemisphere; $F_{(1,20)}=21.44 ; p=0.0002^{9}$, hemisphere $\times$ injury interaction, $n=6$ mice per group; Fig. 1E,F). The increased migration was also independent of distance from the injury, as there was no difference between the dorsal and ventral hippocampus in the injured hemisphere $(p=$ $0.075^{10}$, hippocampal region $\times$ injury interaction); therefore, these regions were combined for further statistical analysis. However, we still maintained matched dorsal and ventral hippocampal regions between groups, and between ipsilateral and contralateral samples. Post-CCI, a small percentage of newborn neurons had even migrated into the molecular layer, which was rarely observed in sham mice $\left(p=0.0028^{11}\right.$; Fig. $\left.1 E, G\right)$. However, unlike other injury models (Parent et al., 1997; Scharfman et al., 2000), CCl did not increase the percentage of cells that migrated into the hilus (sham injury, $3.6 \pm 0.6 \%$; $\mathrm{CCl}, 5.2$ $\pm 1.5 \% ; p=0.44^{12}$ ).

\section{$\mathrm{CCl}$ increases the dendritic complexity of immature neurons born after injury}

During the first two postmitotic weeks, adult-born granule cells extend apical dendrites through the GCL and into the IML of the dentate gyrus (Zhao et al., 2006). As neuronal insults can alter dendritic maturation of adult-born cells (Overstreet-Wadiche et al., 2006; Jessberger et al., 2007; Niv et al., 2012), we analyzed the arborization of neurons born after $\mathrm{CCl}$. Although $\mathrm{GFP}^{+}$cells constitute a relatively restricted, time-defined cohort of adult-born cells (7-14 d postmitosis), this is a stage of rapid dendritic growth. Thus, we more precisely dated the birth of $\mathrm{GFP}^{+}$cells in POMC-EGFP mice by administering BrdU to mice 2, 5, or $7 \mathrm{~d}$ after $\mathrm{CCl}$ or sham injury (studied in three separate cohorts of animals). $\mathrm{BrdU}^{+} / \mathrm{GFP}^{+}$neurons were imaged in three dimensions, and their dendrites were traced at 2 weeks post-CCl for each cohort (Fig. 2A). Sholl analysis revealed that $\mathrm{CCl}$ altered the dendritic structure of immature neurons $\left(F_{(9,740)}=2.846 ; p=0.0027^{13}\right.$; branch points $\times$ treatment interaction; Fig. $2 B$ ), characterized primarily as a selective increase in the number of branches close to the soma $p=0.006,0.0004$, and 0.0001 at 20,30, and 40 $\mu \mathrm{m}$ from the soma, respectively ${ }^{14} ; n=45$ and 31 cells from seven sham- and eight $\mathrm{CCl}$-treated mice with all ages combined; Fig. 2B,C). There was no interaction between treatment and cell age $\left(p=0.76^{15}\right)$, and this is reflected by the persistent effect of $\mathrm{CCl}$ on dendritic structure in each of the three cohorts of 7-d-old cells (sham, 12 cells from two mice; $\mathrm{CCl}, 9$ cells from two mice), 9-d-old cells (sham, 11 cells from three mice; $\mathrm{CCl}$, 12 cells from three mice), and 12-d-old cells (sham, 6 cells from two mice; $\mathrm{CCl}, 11$ cells from three mice; Fig. 2B); therefore, the different cell ages were combined. CCltreated mice also had shorter distances between their somata and first branch point $\left(p=0.0012^{16}\right.$; Fig. $\left.2 C, D\right)$, more dendritic branches $\left(p=0.0005^{17}\right.$; Fig. $2 E$ ), and increased total dendritic length $\left(p=0.001^{18}, n=48\right.$ cells from six sham mice; 52 cells from six CCl-treated mice; Fig. 2F).

\section{Neurons born during post-traumatic neurogenesis have preserved early electrophysiological maturation} To examine the functional properties and synaptic integration of cells born after TBI, we performed currentclamp and voltage-clamp recordings from fluorescently labeled adult-born cells in POMC-EGFP mice 2 weeks after $\mathrm{CCl}$. Immature neurons in the sham injury and $\mathrm{CCl}$ groups had similar passive membrane properties, including high-input resistance and low capacitance, which is typical of immature cells (Espósito et al., 2005; $\mathrm{K}^{+}$-based internal solution: input resistance: sham $=4.3 \pm 0.6 \mathrm{G} \Omega$, $\mathrm{CCl}=3.6 \pm 0.4 \mathrm{G} \Omega, p=0.59^{19}$; capacitance: sham $=7.0$ $\pm 0.7 \mathrm{pF}, \mathrm{CCl}=9.1 \pm 1.2 \mathrm{pF}, p=0.42^{20} ; n=10$ cells from two animals each; $\mathrm{Cs}^{+}$-based internal solution: input resistance: sham $=17.1 \pm 3.1 \mathrm{G} \Omega, \mathrm{CCl}=25.5 \pm 4.5 \mathrm{G} \Omega$, $p=0.14^{21}$; capacitance: sham $=4.9 \pm 0.7 \mathrm{pF}, \mathrm{CCl}=4.8$ $\pm 0.3 \mathrm{pF}, p=0.86^{22} ; n=7,8$ cells from two mice/group). In current-clamp recordings with a $\mathrm{K}^{+}$-based internal solution, neurons born after $\mathrm{CCl}$ had similar resting membrane potentials and spiking properties as sham controls, typically with a single low-amplitude action potential during depolarizing current steps, as reported previously for adult-born neurons (Overstreet et al., 2004; Espósito et al., 2005; Fig. 3A; 8 of 9 cells with only single spikes during prolonged depolarizing current step after sham, 7 of 10 cells with only single spikes after $\mathrm{CCl}$; resting $V_{\mathrm{m}}$ : sham $=-53.6 \pm 4.4 \mathrm{mV}, \mathrm{CCl}=-57.4 \pm 3.5 \mathrm{mV}, p=$ $0.43^{23}$; spike threshold sham $=-30.1 \pm 1.6 \mathrm{mV}, \mathrm{CCl}=$ $-26.6 \pm 2.7 \mathrm{mV}, p=0.33^{24}$; spike amplitude: sham $=$ $39.9 \pm 4.8 \mathrm{mV}, \mathrm{CCl}=53.0 \pm 11.0 \mathrm{mV}, p=0.24^{25} ; n=9$, 10 cells from two mice/group). The action potentials of immature cells born after $\mathrm{CCl}$ were slightly narrower (halfwidth: sham $=3.1 \pm 0.3 \mathrm{~ms}, \mathrm{CCl}=2.6 \pm 0.2 \mathrm{~ms}, p=$ $0.014^{26}$ ) but had similar rise rates (sham $=24.7 \pm 3.8$ $\mathrm{mV} / \mathrm{ms}, \mathrm{CCl}=40.2 \pm 13.3 \mathrm{mV} / \mathrm{ms}, p=0.34^{27} ; n=9,10$ cells from two mice/group).

To assess synaptic currents, we made recordings from immature cells with a $\mathrm{Cs}^{+}$-based internal solution in voltage clamp at various holding potentials. In these experiments, immature adult-born neurons had similar magnitude fast, voltage-dependent (presumably $\mathrm{Na}^{+}$) currents activated by depolarizing voltage steps (Fig. $3 B, C)$. To stimulate excitatory afferents from entorhinal cortex as well as excitatory associational/mossy cell in- 

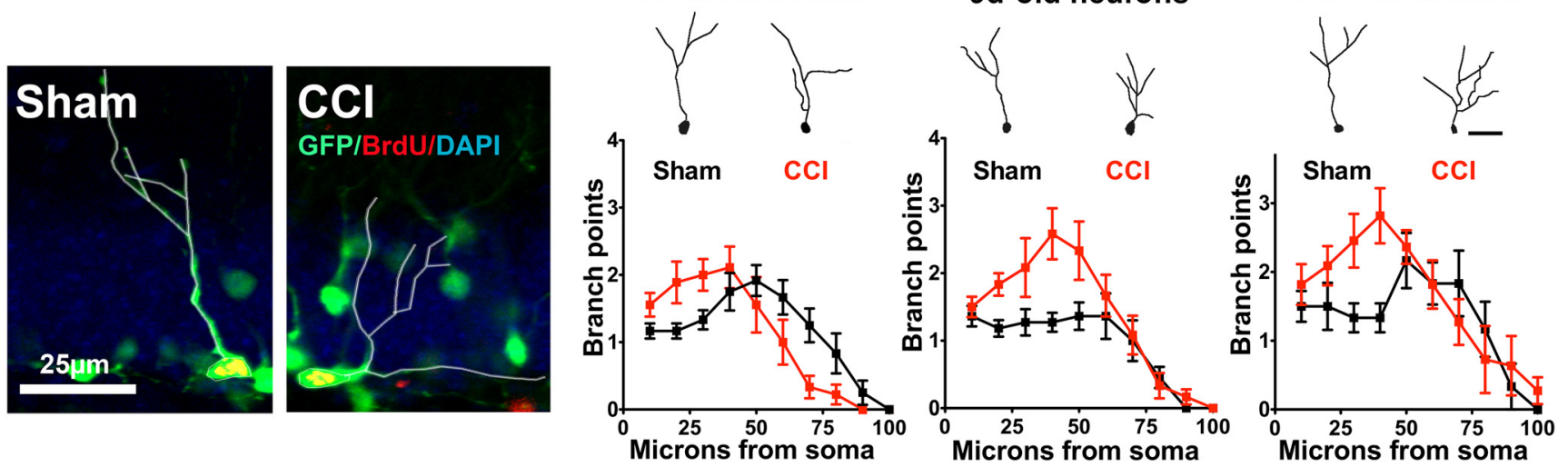

C
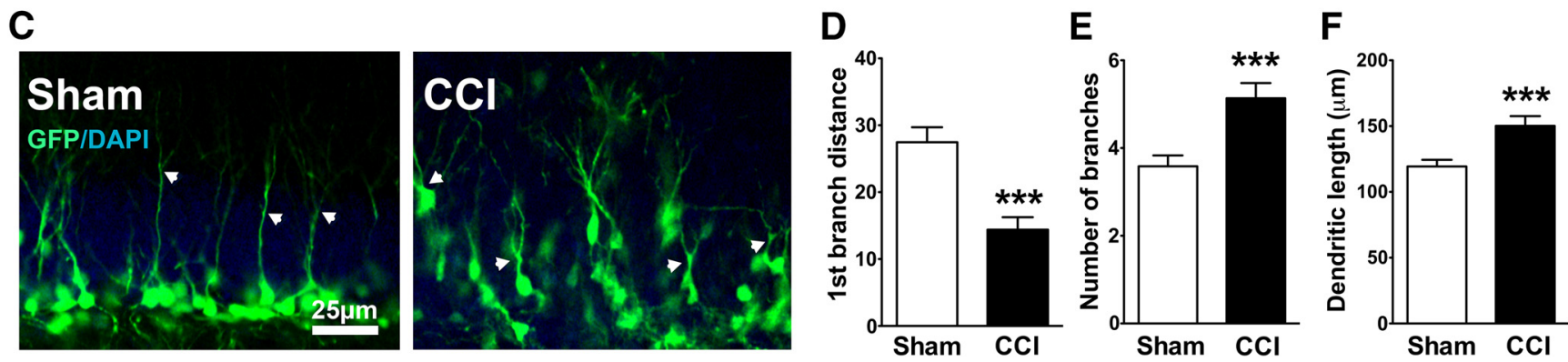

Figure 2. Granule cells born after $\mathrm{CCl}$ have accelerated dendritic growth. $\boldsymbol{A}$, Confocal image of BrdU ${ }^{+}$cells expressing GFP in POMC-EGFP mice, used to precisely date the birth of cells for morphologic analysis. In this example, BrdU was administered to POMC-EGFP mice $5 \mathrm{~d}$ after $\mathrm{CCl}$ or sham procedure and perfusion was fixed at $14 \mathrm{~d}$, so that BrdU ${ }^{+}$cells were $9 \mathrm{~d}$ postmitosis. Traced cells are outlined in white. B, Representative images (top) of dendritic tracings of 7-, 9-, and 12-d-old GFP ${ }^{+}$cells in sham and $\mathrm{CCl}$-treated mice, and the Sholl analyses (bottom) for group data at each time point. In each cohort, $\mathrm{CCl}$ increased the number of dendritic branch points of immature cells born during post-traumatic neurogenesis $\left(p=0.0027^{13}\right)$. Branches also occurred closer to the cell body in CCl-treated mice in each cohort, which was independent of cell age $\left(p=0.76{ }^{15}\right)$. C, Representative images of GFP ${ }^{+}$ cells and their dendritic outgrowth. White arrows point to the first dendritic branch points. $\boldsymbol{D}-\boldsymbol{F}$, GFP ${ }^{+}$cells from CCI treated mice branched closer to their cell body $\left(* * * p=0.0012^{16} ; \boldsymbol{D}\right)$, had more cumulative branches $\left(* * * p=0.0005^{17} ; \boldsymbol{E}\right)$, and had greater total dendritic length $\left(* * * p=0.001^{18} ; \boldsymbol{F}\right)$.

puts located in the IML, we positioned a stimulating electrode at the IML/middle molecular layer border. This stimulation also activates direct inhibitory inputs onto granule cells as well as feedforward inhibitory pathways. In all cells assayed (sham, $n=8 ; \mathrm{CCl}, n=7$ ), electrical stimulation elicited synaptic currents (Fig. $3 D$ ) that were almost completely blocked by the $\mathrm{GABA}_{A} R$ antagonist SR95531 (10 $\mu \mathrm{M}$; Fig. 3E). This result is consistent with prior observations that adult-born granule cells almost exclusively have GABAergic synaptic inputs at this early stage (Espósito et al., 2005; Overstreet Wadiche et al., 2005; Ge et al., 2006). Furthermore, analysis of IPSC decay kinetics demonstrated no difference between groups (sham $\tau=138 \pm 16 \mathrm{~ms}$; $\mathrm{CCl} \tau=138 \pm 20 \mathrm{~ms} ; p$ $=0.99$ ).

In the presence of $\mathrm{GABA}_{\mathrm{A}} \mathrm{R}$ blockade, we elicited small, slowly decaying currents at $+40 \mathrm{mV}$ in a proportion of cells in each group (three of seven cells in sham mice, four of seven in $\mathrm{CCl}$ mice), which were consistent with prior demonstration of NMDAR-only excitatory synapses in $\sim 50 \%$ of cells in this immature population (Chancey et al., 2013). However, at $-70 \mathrm{mV}$, only one cell (in a post-sham injury mouse, of seven cells assayed in each group) had a small AMPAR-mediated response (10 pA) despite supra- maximal stimulation. Although we used a high stimulation intensity to evoke responses, to eliminate the possibility that we failed to excite excitatory afferents due to electrode position, we also looked for sEPSCs. However, none of the cells had more than two putative events in 10 min of continuous recording per cell, with the majority of cells having no events. Thus, we conclude that the sEPSC frequency was extremely low $(<0.002 \mathrm{~Hz})$, with no difference in SEPSC frequency between conditions (sham sEPSC frequency $=0.0005 \pm 0.0004 \mathrm{~Hz} ; \mathrm{CCl}$ sEPSC frequency $=0.0013 \pm 0.0007 \mathrm{~Hz} ; p=0.24^{28} ; n=7$, six cells from two mice/group).

Consistent with the absence of excitatory synaptic activity, there were no dendritic spines detected in $\mathrm{GFP}^{+}$ neurons from sham- or CCl-treated mice (Fig. $3 F, G$ ). Thus, although the mild heterogeneity in postmitotic age of $\mathrm{GFP}^{+}$cells (Overstreet et al., 2004) may have obscured minor electrophysiological differences between groups, immature adult-born cells developing post-CCl show the expected early functional maturation of normal adult-born granule cells. This includes the development of intrinsic excitability and GABAergic synapses at an early maturational stage without any precocious maturation of excitatory synapses. 
Immature Adult-Born Granule Cells

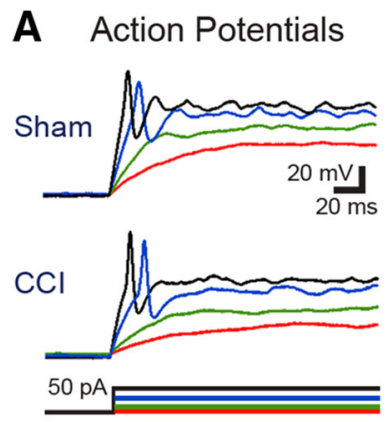

B
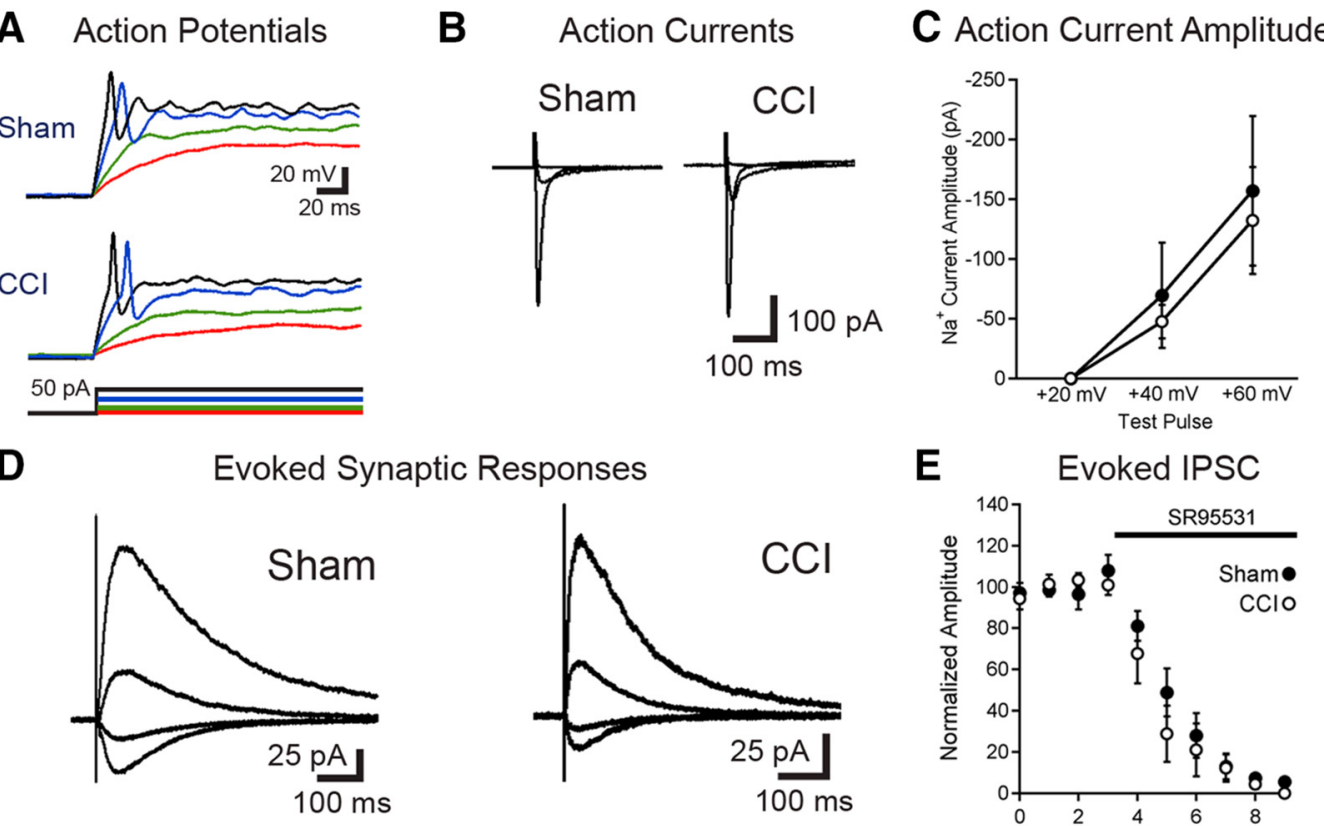

naptic Responses

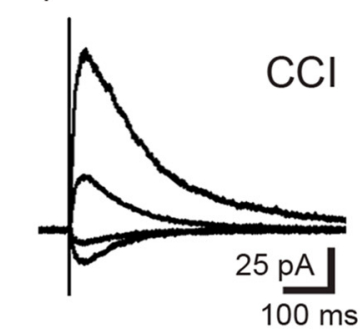

E

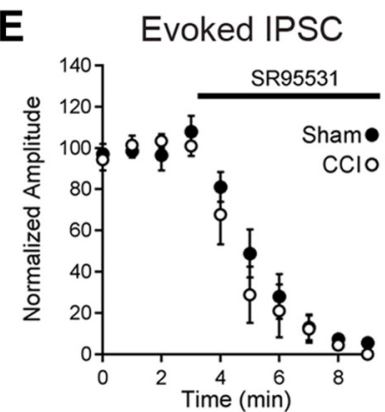

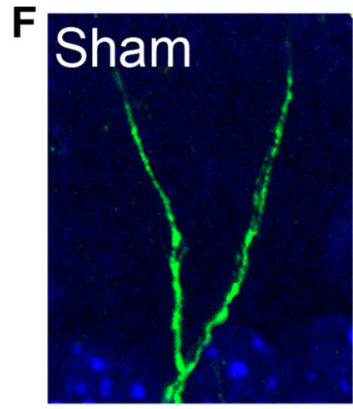

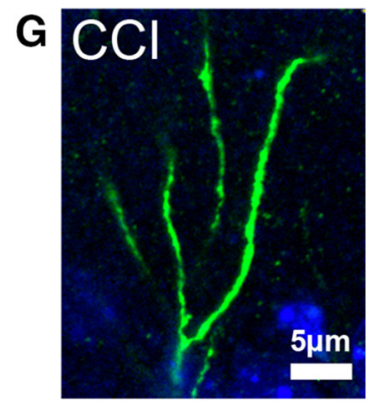

Figure 3. Immature granule cells born after TBI are excitable and integrated into the hippocampal circuitry. $\boldsymbol{A}$, Current-clamp recordings from GFP-positive immature granule cells born after sham or CCI surgery demonstrate that cells born after TBI fire action potentials during depolarizing current injection. Respective voltage traces during current injections of $+5 \mathrm{pA}$ (red), $+10 \mathrm{pA}$ (green), $+30 \mathrm{pA}$ (blue), and $+40 \mathrm{pA}$ (black) for both sham and CCl-treated animals are shown. Summary data are given in the text. $\boldsymbol{B}$, $\boldsymbol{C}$, Single-cell, voltage-clamp recordings demonstrate that immature granule cells have similar voltage-dependent action currents. $\boldsymbol{B}$, Averaged action currents from example cells during steps of $+20,+40$, and $+60 \mathrm{mV}$ from a holding potential of $-70 \mathrm{mV}$. C, Summary data of the amplitude of the action current response in response to the various steps between groups (sham $=7 \mathrm{cells}$; CCl $=7 \mathrm{cells}$; $p=0.65^{54}$ with a $+40 \mathrm{mV}$ step; $p=0.75^{55}$ with a $+60 \mathrm{mV}$ step). $\boldsymbol{D}$, Synaptic currents elicited in immature adult-born neurons in response to stimulation at the IML/MML border, while voltage clamping the cells to $-70,-40,0$, and $+40 \mathrm{mV}$. $\boldsymbol{E}$, Summary data of response amplitudes of evoked currents (recorded while clamping cells at $+40 \mathrm{mV}$ ), demonstrating almost complete block of the evoked synaptic response by the GABA ${ }_{A} R$ antagonist SR95531 (10 $\mu \mathrm{M} ; n=5$ cells per group). $\boldsymbol{F}$, G, High-power imaging of dendrites from newborn neurons in sham and CCl-treated mice show no evidence of dendritic spines on immature GFP ${ }^{+}$cells in either condition.

\section{Persistent survival and ectopic migration of mature neurons born shortly after $\mathbf{C C l}$}

Our results to this point with POMC-EGFP-labeled cells indicate that up to 2 weeks post-CCI, cells born after TBI have abnormal dendritic development and migration, but grossly normal electrical and synaptic properties. However, changes that might appear in these cells during their subsequent maturation could not be assessed with this mouse, as cells in POMC-EGFP mice no longer express GFP at 1 month postmitosis. Thus, we used DcxCre/ tdTom mice to pulse label the granule neurons born in the first few days following $\mathrm{CCl}$, so that we could analyze this same cohort of cells at a later time point. In these mice, immature adult-born neurons express a tamoxifen-inducible Cre recombinase, CreER ${ }^{T 2}$, under the control of the doublecortin promoter (Cheng et al., 2011). These mice were crossed to a Cre-dependent marker mouse (Rosa26-CAGtdTomato), such that tamoxifen permanently induced tdTomato expression in a cohort of immature cells, allowing them to be examined after they matured. We administered tamoxifen 6-8 $\mathrm{d}$ after $\mathrm{CCl}$ or sham treatment and assessed labeled neurons at 1 month after $\mathrm{CCl}$.
Although well characterized in the original report (Cheng et al., 2011), we confirmed that tamoxifen administration induced tdTom expression in immature cells by examining Dcx costaining early after tamoxifen treatment (Fig. $4 A$, left), which confirmed that tdTom ${ }^{+}$cells were all immature adult-born cells at this time point. Over the next 3 weeks, these cells matured in vivo, losing Dcx expression and acquiring a more mature morphology (Fig. $4 A$, right). Cells born after tamoxifen treatment were not recruited into the tdTom-labeled pool after tamoxifen withdrawal, based on both the lack of Dcx/tdT costaining at later time points (Fig. $4 A$, right) and the lack of tdTom expression in cells born after tamoxifen as assessed by BrdU colabeling (Fig. 4B). Thus, the DcxCre/tdTom mice allowed us to examine the long-term fate of granule cells born during early post-traumatic neurogenesis.

As expected, there were more tdTom ${ }^{+}$neurons in $\mathrm{CCl}-$ treated mice compared to sham mice at this interval $(p=$ $0.0087^{29}, n=6$ mice/group; Fig. $5 A, B$ ). The increase in tdTom ${ }^{+} \mathrm{CCl}$-induced newborn neurons was greater than the increase in CCl-treated POMC-EGFP mice (compare Figs. $1 C, 5 B$ ). This difference may have been due to slight 

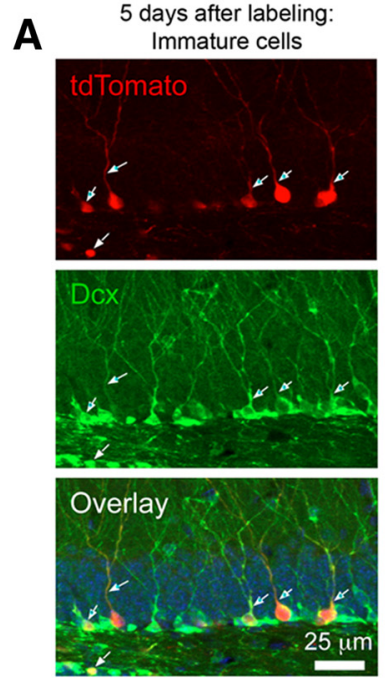

26 days after labeling: More mature cells
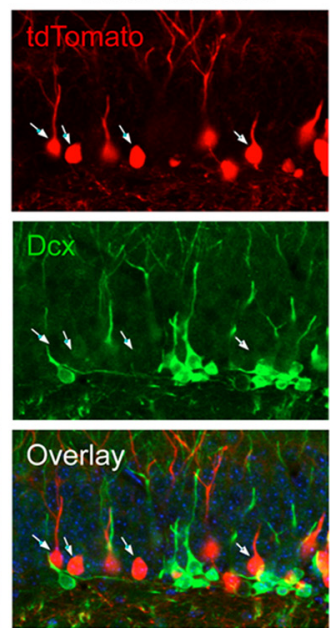

B BrdU 3 days before TAM
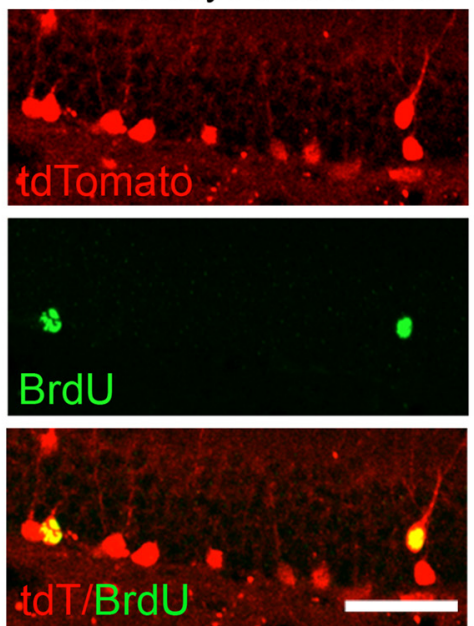

\section{BrdU 3 days after TAM}
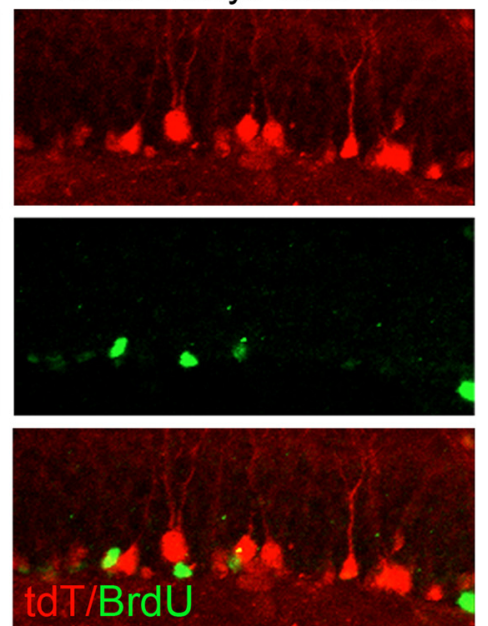

Figure 4. Tamoxifen administration pulse labels adult born neurons in DcxCre/tdTomato mice. $\boldsymbol{A}$, Tamoxifen (TAM) was administered to adult DcxCre/tdTom mice, and they were fixed at two different time intervals thereafter. Early after TAM administration (left), $\mathrm{tdTom}^{+}$cells have immature dendritic morphologies and stain for the immature marker Dcx, indicating recent mitosis. After 3 weeks (right), tdTom ${ }^{+}$cells no longer costain for Dcx, suggesting that labeled cells mature, and that no new immature cells have been labeled. The minor overlap of red and green in the projected image at $26 \mathrm{~d}$ after TAM administration reflects the overlap of separate cells in the stack and not coexpression. $\boldsymbol{B}$, DcxCre/tdTom mice received BrdU to mark cells born either before (left) or after (right) adult TAM administration, and were fixed 3 weeks later. Cells born before TAM administration are efficiently labeled by tdTom expression, but cells born after TAM did not express tdTom, indicating that neurons born just prior to tamoxifen administration are selectively pulse labeled. Scale bar, $50 \mu \mathrm{m}$.

differences in the exact cohort of cells sampled in POMCEGFP mice versus DcxCre/tdTom mice, as there is a biphasic change in neurogenesis following $\mathrm{CCl}$, with an initial reduction followed by a subsequent increase in proliferation in the dentate gyrus (Yu et al., 2008).
The increased outward migration of cells born after $\mathrm{CCl}$ (Fig. 1D-F) was still apparent at this later time point when compared to matched samples from sham mice $(p=$ $0.042^{30}, n=6$ mice/group; Fig. $5 C, D$ ). The ectopic migration of adult-born neurons into the molecular layer also
A

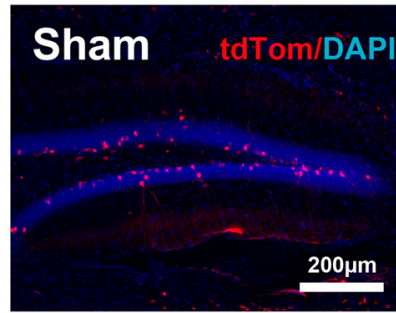

C

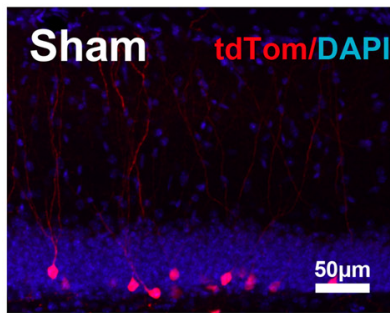

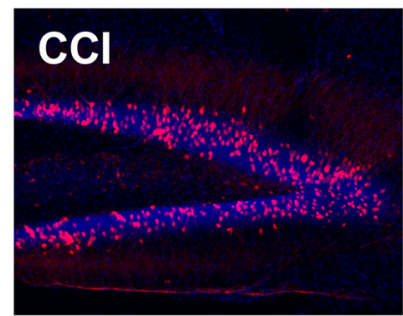

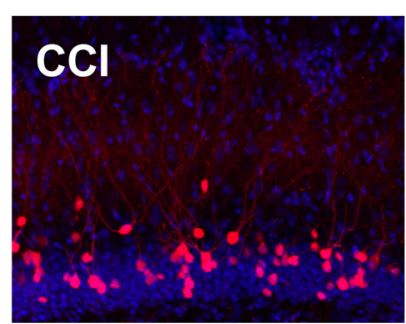

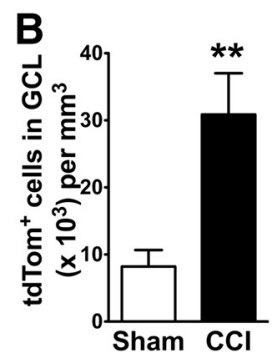

D

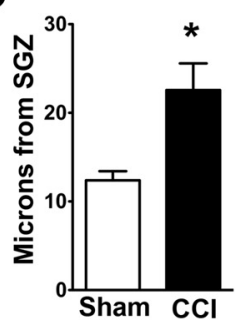

Figure 5. Neurons born shortly after $\mathrm{CCl}$ survive and maintain their aberrant localization in maturity. A, Representative images of $\sim$-week-old tdTom ${ }^{+}$cells from the ipsilateral hippocampus of DcxCre/tdTom sham and CCl-treated mice, in which cells born after $\mathrm{CCl}$ were permanently pulse labeled with tdTomato. $\boldsymbol{B}$, One month after injury, CCl-treated mice had more tdTom ${ }^{+}$cells in the ipsilateral granule cell layer of the dentate gyrus compared with sham mice $\left(* * p=0.0087^{29}, n=6\right.$ mice/group). $\boldsymbol{C}$, Representative images of tdTom ${ }^{+}$cell dispersion in the granule cell layer of the ipsilateral dentate gyrus. $\boldsymbol{D}, \mathrm{CCl}$-treated mice had greater cell migration in the ipsilateral dentate gyrus compared with sham mice ( $* p=0.042^{30}, n=6$ mice/group). 
A
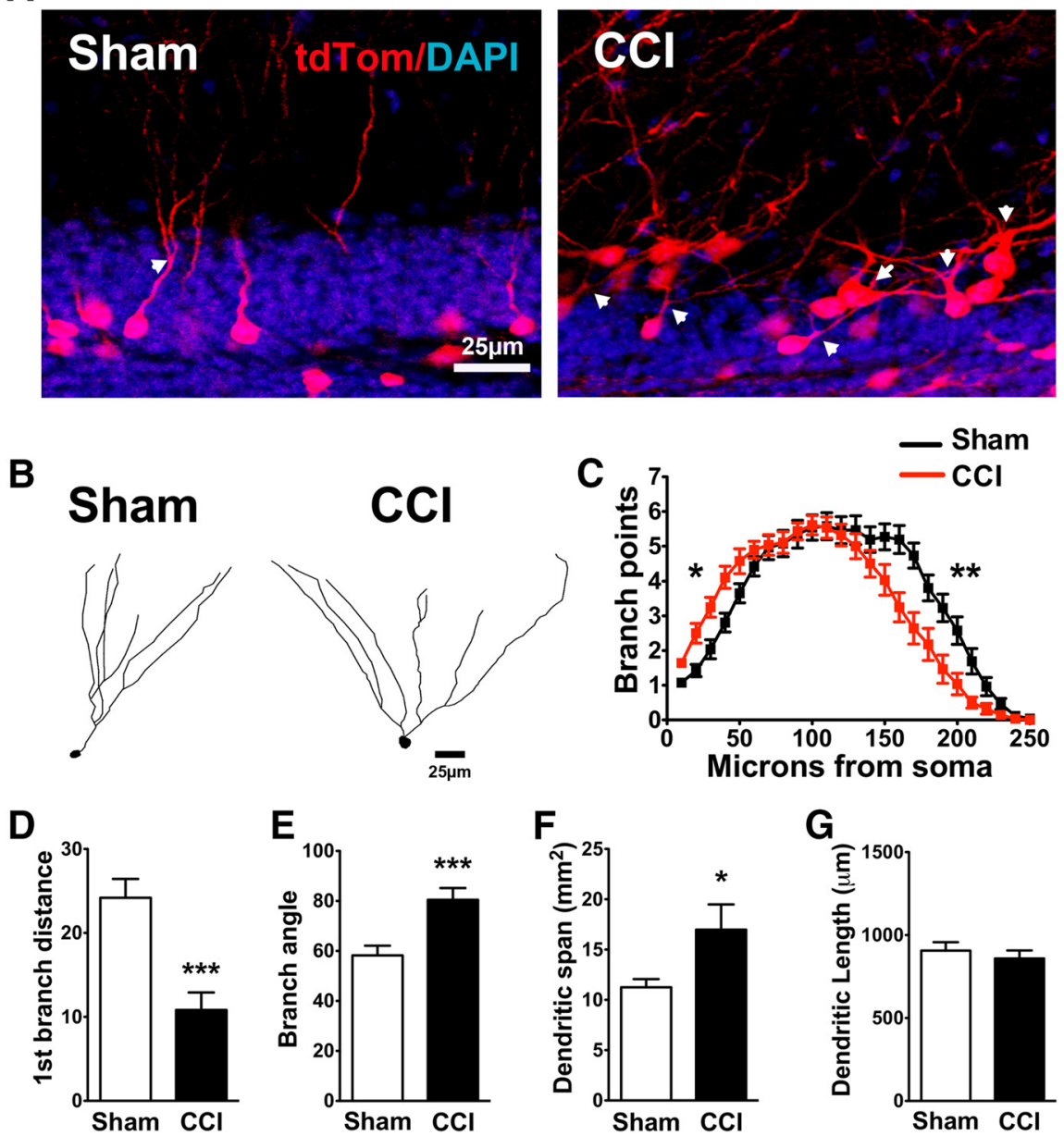

Figure 6. $\mathrm{CCl}$-induced changes in the dendritic morphology of newborn neurons persist as these cells mature. $\boldsymbol{A}$, Representative images of 4-week-old tdTom ${ }^{+}$cells from sham and CCl-treated mice. Arrows point to the first dendritic branch point of selected cells. $\boldsymbol{B}$, Representative tracings of tdTom ${ }^{+}$cells from sham and $\mathrm{CCl}$-treated mice. $\boldsymbol{C}$, Sholl analyses of dendritic arborization of tdTom ${ }^{+}$ cells reveal a CCl-induced persistent increase in the number of branch points observed near the soma $(* p=0.0001,0.003,0.004$, 0.003 , and 0.049 for each $10 \mu \mathrm{m}$ increment between 10 and $50 \mu \mathrm{m}$ from the soma $\left.{ }^{34}\right)$, but a reduction in more distal regions ( $* * p=$ $0.038,0.002,0.001,0.009,0.003,0.003,0.004$, and 0.038 for each $10 \mu \mathrm{m}$ increment between 150 and $220 \mu \mathrm{m}$ from the soma ${ }^{34} ; n$ $=26$ cells from 7 sham mice; 28 cells from 8 CCl-treated mice). $\boldsymbol{D}-\boldsymbol{F}$, tdTom ${ }^{+}$cells from CCl-treated mice branched closer to their cell body $\left(* * * p=0.0001^{35} ; \boldsymbol{D}\right)$, and had wider angles $\left(* * * p=0.0007^{36} ; \boldsymbol{E}\right)$ and area $\left(* p=0.040^{37} ; \boldsymbol{F}\right)$ between the dendrites that were farthest apart. $\mathbf{G}$, tdTom $^{+}$cells from sham and CCl-treated mice had similar cumulative dendritic lengths $\left(p=0.50^{56}\right)$.

persisted $\left(p=0.01^{31} ;\right.$ tdTom $^{+}$cells in the molecular layer: sham $=0 \% \pm 0 ; \mathrm{CCl}=7.1 \% \pm 2.4, n=6$ mice/group), suggesting that the ectopically migrated cells survive and maintain their aberrant localization.

\section{Persistent aberrations in dendritic morphology of mature cells born shortly after $\mathbf{C C l}$}

At 1 month after injury, pulse-labeled tdTom ${ }^{+}$cells born after $\mathrm{CCl}$ continued to display an altered pattern of dendritic arborization, as determined by Sholl analysis $\left(F_{(29,1560)}=5.0 ; p=0.0001^{32}\right.$, distance $\times$ treatment interaction, two-way repeated-measures ANOVA, $n=26$ cells from seven sham mice; 28 cells from eight $\mathrm{CCl}$ treated mice; Fig. $6 A-C$ ). This effect was independent of the location of the cells within the GCL, as a significant effect of $\mathrm{CCl}$ was still present when we compared cells from sham and $\mathrm{CCl}$-treated mice that had similar migra- tion distances $\left(F_{(29,522)}=1.615 ; p=0.021^{33}\right.$, branch point $\times$ treatment interaction, $n=9,11$ cells from three mice/ group).

Morphologically, tdTom ${ }^{+}$cells in both the sham and $\mathrm{CCl}$ groups had more extensive dendritic trees than $\mathrm{GFP}^{+}$ cells in POMC-EGFP mice, which is consistent with their further maturation in vivo, as tdTom ${ }^{+}$cells are $\sim 1$ month postmitosis compared with 7-14 d postmitosis for POMC$\mathrm{EGFP}^{+}$cells. Similar to immature neurons in POMC-EGFP mice, mature cells born after $\mathrm{CCl}$ had more proximal branches (Fig. 6C, left side of distance axis on the Sholl plot; $p=0.0001,0.003,0.004,0.003$, and 0.049 for each $10 \mu \mathrm{m}$ increment between 10 and $50 \mu \mathrm{m}$ from the soma $^{34}$ ), with the first proximal branch occurring closer to the cell soma $\left(p=0.0001^{35}\right.$; Fig. $\left.6 D\right)$. At farther distances, however, there were fewer branches compared with sham mice $(p=0.038,0.002,0.001,0.009,0.003,0.003,0.004$, 
A
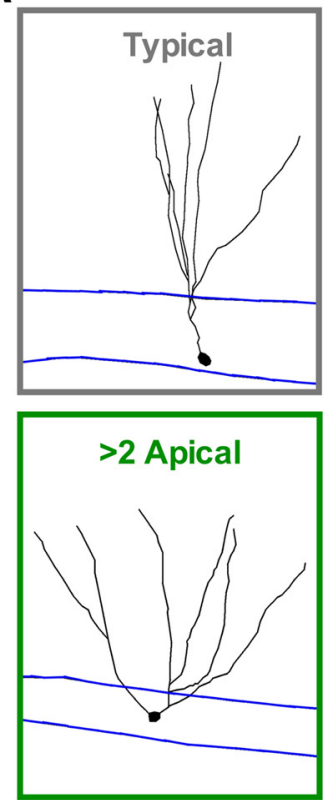
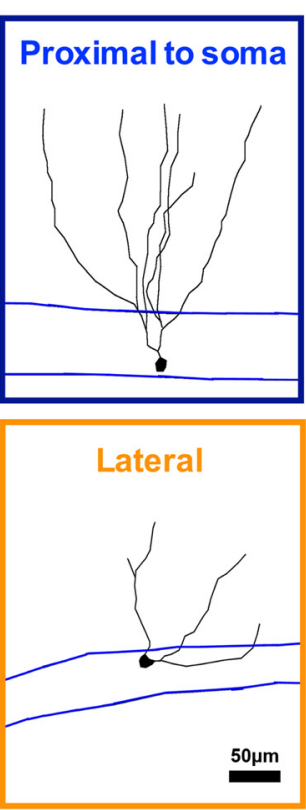

B

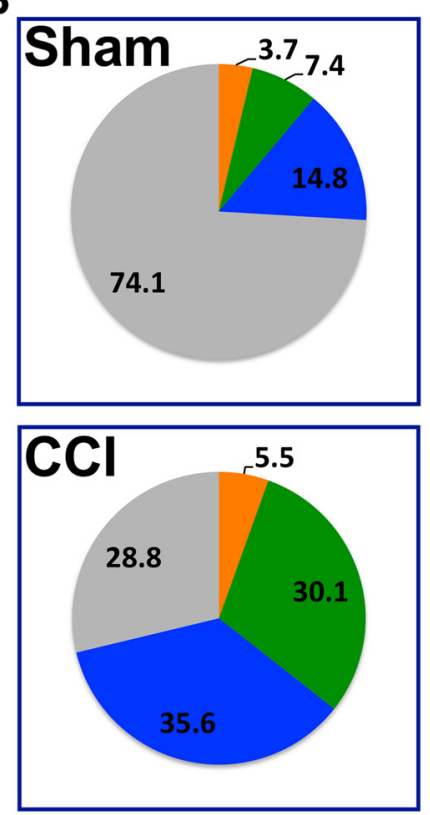

Figure 7. $\mathrm{CCl}$ increased the heterogeneity of dendritic branch morphology in cells born after injury. $\boldsymbol{A}$, Representative morphology of $\mathrm{tdTom}^{+}$cells categorized according to their dendritic phenotype. $\boldsymbol{B}$, The majority of tdTom ${ }^{+}$cells in sham mice were characterized by a single apical dendrite that branched farther away from the cell body ( $>10 \mu \mathrm{m}$ from soma, typical cell), whereas the majority of tdTom $^{+}$cells in CCl-treated mice branched more proximal to their somata $(<10 \mu \mathrm{m})$, had more than one apical dendrite, or had an apical dendrite that projected laterally from their soma $\left(<30^{\circ}\right.$ from GCL). There were fewer typical tdTom ${ }^{+} \mathrm{cells}$ in $\mathrm{CCl}$-treated mice compared with sham mice ( $p=0.021^{38}, n=5$ mice/group).

and 0.038 for each $10 \mu \mathrm{m}$ increment between 150 and $220 \mu \mathrm{m}$ from the soma ${ }^{34}$; Fig. 6C).

Interestingly, tdTom ${ }^{+}$cells from CCl-treated mice had wider angles between primary dendrites $\left(p=0.0007^{36}\right.$; Fig. 6E), and their dendritic arbor covered a wider area of the molecular layer $\left(p=0.0398^{37}\right.$; Fig. $6 F ; n=26$ cells from seven sham mice; $n=28$ cells from eight $\mathrm{CCl}-$ treated mice). Mature granule cells born during posttraumatic neurogenesis also had a notable increase in morphologic heterogeneity (Fig. 7), including cells with lateral projecting dendrites, with more than one apical dendrite, and with a major dendritic branch just adjacent to their soma $(<10 \mu \mathrm{m})$. This effect was coincident with a decrease in the proportion of cells with "typical" morphology, which was defined as a single apical dendrite directed toward the molecular layer $\left(p=0.021^{38}, \mathrm{CCl}\right.$ vs sham mice; $n=5$ mice per group).

\section{Neurons born after $\mathrm{CCl}$ functionally integrate into the hippocampal circuit 1 month after injury}

Despite the aberrant morphology and outward migration of adult-born cells in mice after $\mathrm{CCl}$, tdTom ${ }^{+}$cells in acute hippocampal slices in 3-month-old mice (1 month after $\mathrm{CCl}$ or sham injury) had the same passive membrane properties as labeled cells in sham animals, as assessed using single-cell recording techniques $\left(\mathrm{K}^{+}\right.$-based internal solution: input resistance: sham $=1080 \pm 120 \mathrm{M} \Omega ; \mathrm{CCl}=$ $1450 \pm 430 \mathrm{M} \Omega ; p=0.54^{39}$; capacitance: sham $=37.8 \pm$ $3.0 \mathrm{pF} ; \mathrm{CCl}=41.2 \pm 5.7 \mathrm{pF} ; p=0.0 .68^{40} ; n=7$ from two sham mice, 10 cells from three CCl-treated mice). Likewise, the properties of action potentials evoked by depo- larizing current injection (Fig. $8 A$ ) and resting membrane potentials were similar between groups (resting $V_{\mathrm{m}}$ : sham $=-76.0 \pm 2.3 \mathrm{mV} ; \mathrm{CCl}=-75.5 \pm 2.6 \mathrm{mV} ; p=0.90^{41}$; spike threshold sham $=-38.7 \pm 1.3 \mathrm{mV} ; \mathrm{CCl}=-38.1 \pm$ $1.7 \mathrm{mV} ; p=0.83^{42}$; spike amplitude from threshold: sham $=121.2 \pm 1.3 \mathrm{mV} ; \mathrm{CCl}=116.2 \pm 8.1 \mathrm{mV} ; p=$ $0.66^{43} ; n=6,11$ cells from two sham, three $\mathrm{CCl}$-treated mice). By 1 month after injury, cells born after sham injury or $\mathrm{CCl}$ did have faster action potentials than this same population of cells when sampled earlier (at 2 weeks after injury in POMC-EGFP mice), but action potential halfwidth was no longer significantly different (sham $=1.1 \pm$ $0.1 \mathrm{~ms}, \mathrm{CCl}=1.3 \pm 0.3 \mathrm{~ms}, p=0.66^{44} ; n=6$ and 11 cells from two and three $\mathrm{CCl}$-treated mice). Action potential firing rates, spike frequency accommodation, and spike afterhyperpolarization were also similar between cells (data not shown).

To assess the functional synaptic integration of cells born after TBI, we then performed whole-cell, voltageclamp recordings from tdTom ${ }^{+}$cells using a cesiumbased internal solution to assay synaptic currents at a variety of holding potentials. All cells tested in each group had detectable mEPSCs (Fig. 8B). The amplitude and frequency of mEPSCs were similar between conditions (Fig. $8 C$ ), suggesting that both the strength of individual excitatory synapses as well as the total number of functional excitatory synapses were not different between adult-born cells from each group. The results were similar when SEPSCs were recorded in the absence of TTX, to include action potential-dependent events (average 
Adult-born granule cells, one month after $\mathrm{CCl}$

A

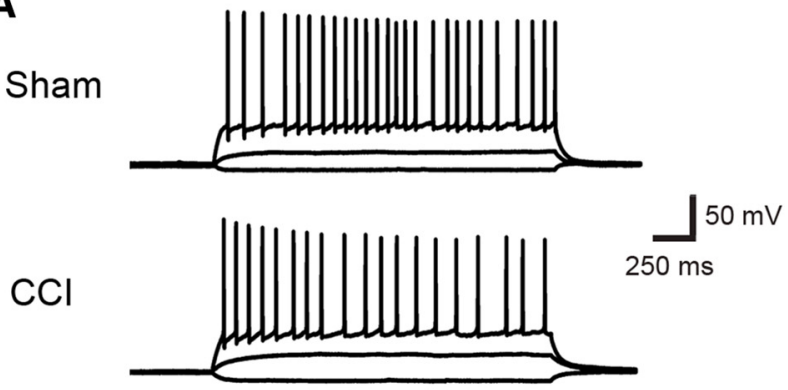

C
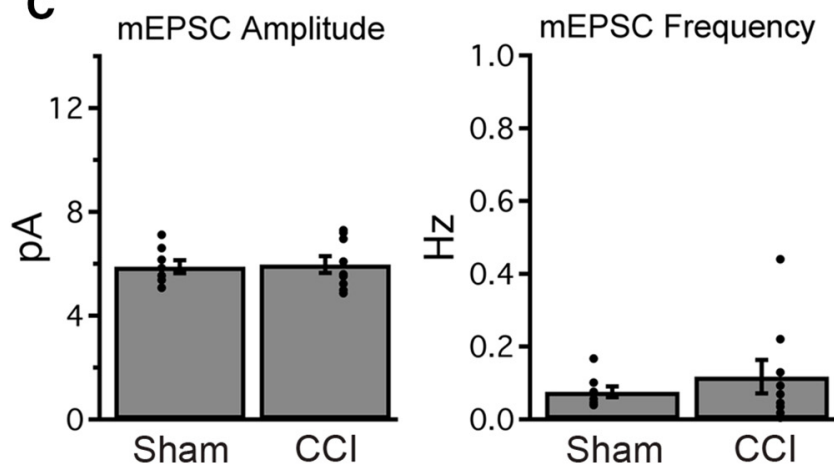

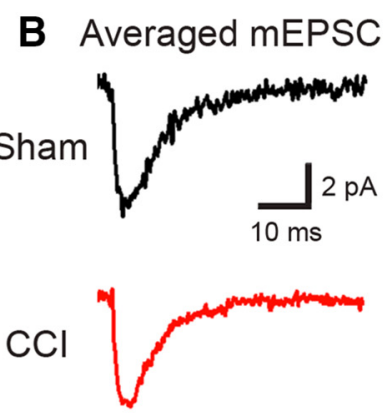

D

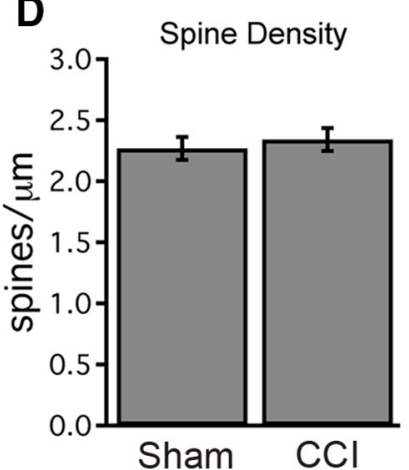

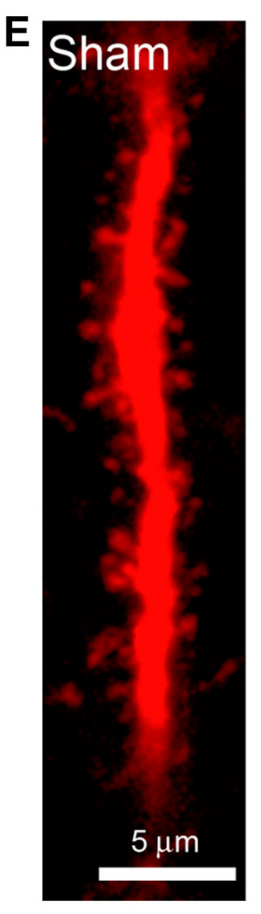

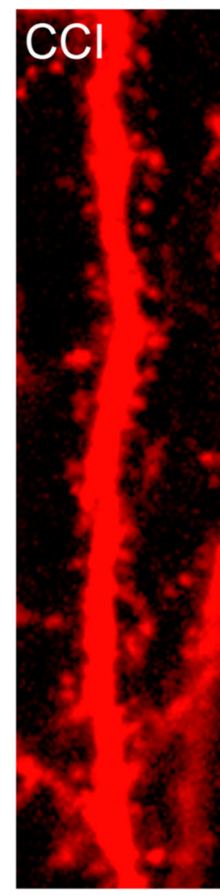

Figure 8. Granule cells born after TBI become functionally integrated into the hippocampal circuit. $\boldsymbol{A}$, At 1 month after injury, single-cell recordings demonstrate normal firing patterns and the excitability of cells born early after TBI. Voltage traces show the response of adult-born granule cells to current injections of $-10,+10$, and $+50 \mathrm{pA}$. $\boldsymbol{B}, \boldsymbol{C}$, Whole cell, voltage-clamp recordings of mEPSCs demonstrate that cells born after TBI acquire excitatory synaptic connections $(\boldsymbol{B})$, and that mEPSC amplitude and frequency (C) are similar to those recorded from adult-born cells of similar age in sham animals $(n=8$ and 9 cells for sham and CCl, respectively; $p>0.4$ each). Each graph depicts summary data (bars) and individual cell data (points). $\boldsymbol{D}$, At 1 month after injury, cells born early following TBI possess dendritic spines within the dentate molecular layer, and dendritic spine density is similar in cells born after sham or $\mathrm{CCl}$ procedures (sham, $n=16$ cells; $\mathrm{CCl}, n=22$ cells; $p=0.60^{53}$ ). $\boldsymbol{E}$, Images of dendritic spines from cells born after $\mathrm{CCl}$ or sham procedure.

sEPSC amplitude: sham $=6.7 \pm 0.5 \mathrm{pA}, \mathrm{CCl}=6.9 \pm 0.4$ $\mathrm{pA}, p=0.72^{45}$; sEPSC frequency: sham $=0.10 \pm 0.02$ $\mathrm{Hz}, \mathrm{CCl}=0.19 \pm 0.06 \mathrm{~Hz}, p=0.29^{46} ; n=7$ and 11 cells from three mice/group). The sEPSC kinetics also did not demonstrate differences between groups (decay $\tau$ : sham $=6.9 \pm 0.3 \mathrm{~ms} ; \mathrm{CCl}=6.8 \pm 0.5 \mathrm{~ms}, p=0.18^{47} ; n=7$ and 11 cells). Finally, as the activity of inhibitory circuits can change after TBI (Santhakumar et al., 2001), we examined inhibitory synaptic currents while holding cells at the reversal potential for excitatory currents. Both the frequency and amplitude of sIPSCs was unchanged between cells born after $\mathrm{CCl}$ or a sham procedure (sIPSC amplitude: sham $=10.9 \pm 0.8 \mathrm{pA}, \mathrm{CCl}=10.5 \pm 1.8 \mathrm{pA}$, $p=0.88^{48}$; sIPSC frequency: sham $=0.53 \pm 0.28 \mathrm{~Hz}$, $\mathrm{CCl}=0.38 \pm 0.25 \mathrm{~Hz}, p=0.70^{49} ; n=6$ and 7 cells from three mice/group). Thus, despite significant changes in the dendritic architecture, cells born during posttraumatic neurogenesis acquire synaptic innervation typical of adult-born neurons at this stage. In accord with these findings, $\mathrm{CCl}$ did not alter the dendritic spine density of tdTom ${ }^{+}$adult-born granule cells (Fig. 8D,E).

Spontaneous and miniature excitatory synaptic events can arise from synapses located across the entire cell, and sample both mossy cell inputs from the hilus as well as entorhinal afferents. Thus, to focus more specifically on afferent (extrinsic) connectivity, we directly evoked excitatory responses arising from entorhinal afferents as well as inhibitory responses from direct and feedforward inhibitory pathways (Freund and Buzsáki, 1996). Stimulation of the molecular layer evoked excitatory and inhibitory synaptic currents in all cells (Fig. 9A). Although neuronal injury can cause an imbalance between excitatory and inhibitory innervation (El-Hassar et al., 2007), cells born after TBI had a normal ratio of excitation to inhibition $(p=$ $0.42^{50}, n=9$ and 13 cells, from three mice/group; Fig. $9 A, B)$. Cells born after $\mathrm{CCl}$ also had a normal ratio of AMPAR/NMDAR-mediated currents $\left(p=0.77^{51} ; n=11\right.$ and 16 cells from three mice/group; Fig. $9 A, C$ ). Finally, paired-pulse facilitation of the evoked EPSC, a measure of presynaptic function, was not different between groups (Fig. 9D,E). Thus, despite persistent morphologic abnormalities, granule cells born after TBI not only fully integrated into the hippocampal circuit, but maintained intact functional properties.

\section{Discussion}

It is now well established that injuries such as TBI can increase neurogenesis in the dentate gyrus (Dash et al., 


\section{A}

\section{Evoked Responses}

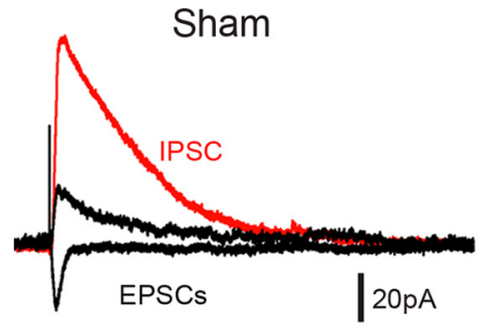

B

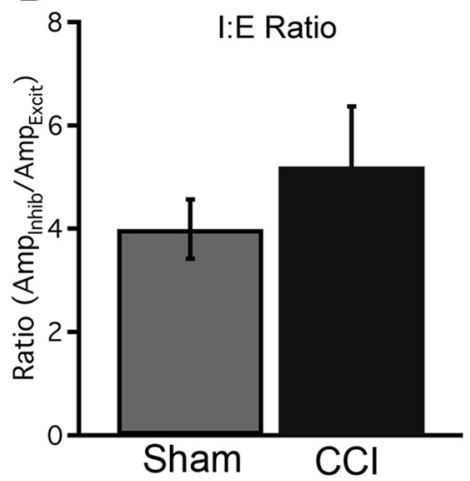

D

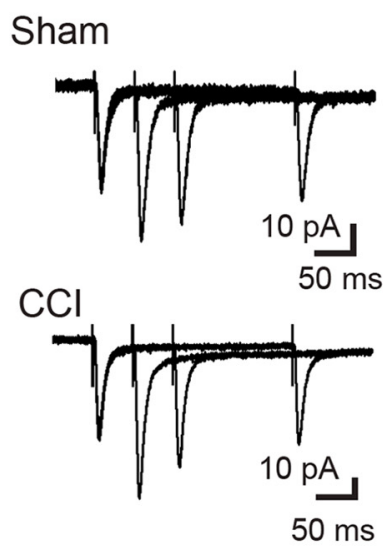

$\mathrm{CCl}$

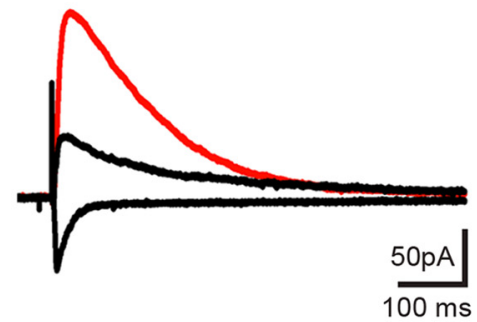

C

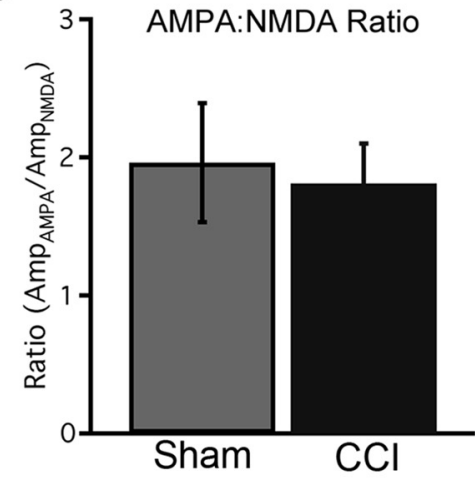

E Paired Pulse Facilitation

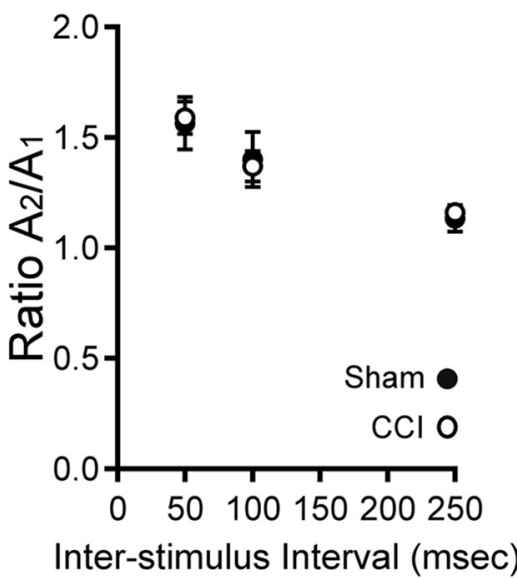

Figure 9. Granule cells born after TBI acquire perforant path inputs and maintain balanced functional connectivity between signaling pathways. A, Stimulation of the dentate molecular layer evokes both excitatory and inhibitory currents in cells born after sham and $\mathrm{CCl}$ procedures. Inhibitory currents were recorded while voltage clamping adult-born cells to $0 \mathrm{mV}$ (red traces), and excitatory currents (black) were recorded at -70 and $+40 \mathrm{mV}$ in the presence of the GABA $\mathrm{R}$ inhibitor SR95531, with the stimulation intensity and electrode position kept constant. $\boldsymbol{B}$, The ratio of evoked inhibitory current amplitude (at $0 \mathrm{mV}$ ) to excitatory current amplitude (AMPAR mediated at $-70 \mathrm{mV}$ ) was measured for single cells with the same stimulation parameters. This inhibition/excitation ratio (I:E ratio) was similar for cells born after sham or $\mathrm{CCI}\left(p=0.42^{50} ; n=9\right.$ and 13 cells). $\boldsymbol{C}$, The ratio of AMPAR- to NMDAR-mediated currents at perforant path synapses was similar for cells born after $\mathrm{CCI}\left(p=0.77^{51} ; n=11\right.$ and 16 cells). $\boldsymbol{D}, \boldsymbol{E}$, Paired-pulse facilitation was not different at perforant path synapses for cells between groups. $\boldsymbol{D}$, Example traces show overlaid pairs of responses with interpulse intervals of 50, 100, and $250 \mathrm{~ms}$ for cells born after both sham and CCl. $\boldsymbol{E}$, Summary data show no difference in paired-pulse facilitation between groups $\left(p=0.86^{52}, 0.82^{52}\right.$, and $0.68^{52}$ for 50,100 , and 250 ms interspike intervals, respectively; sham, $n=8$; CCl, $n=11$ cells from 3 mice/condition).

2001; Chirumamilla et al., 2002; Villasana et al., 2014). However, the subsequent fate and function of these adultborn granule cells has been challenging to study, as they are anatomically interspersed among an abundance of mature granule cells (Aimone et al., 2014). Retroviral labeling techniques allow for long-term tracing of adult- born cells as well as electrophysiological analysis (van Praag et al., 2002), although this requires a direct intrahippocampal injection of viral particles, which itself induces trauma that could confound analysis. Our use of POMC-EGFP and DcxCre/tdTom transgenic mice allowed us to study the fate of adult-born granule cells early 
after their generation and weeks later, respectively. Our results indicate that the adult-born granule cells generated post-TBI survive and become integrated into the hippocampal network, thus leading to a net increase in the cohort of functional new neurons born following TBI. Neurons born after TBI acquired typical levels of synaptic innervation, and maintained a balance between excitatory and inhibitory synaptic activity that was similar to that of age-matched adult-born neurons from sham mice.

In addition to the increased production of new neurons after injury, we observed that $\mathrm{CCl}$ altered the migration and morphologic development of cells born after injury. Changes in the migration and dendritic development of adult-born neurons have also been observed following other types of brain injuries, including experimental stroke (Niv et al., 2012), neonatal hypoxia (Pugh et al., 2011), entorhinal cortical lesions (Perederiy et al., 2013), and seizures (Scharfman et al., 2000; Jessberger et al., 2007; Shapiro et al., 2008). However, changes in the development of adult-born neurons appear to be injury specific. For example, experimental temporal epilepsy and stroke respectively increase the development of spines and spine density of newborn neurons born after injury (Overstreet-Wadiche et al., 2006; Niv et al., 2012). In contrast, we did not find accelerated development of spines in young neurons born after $\mathrm{CCl}$ or changes in the spine density of older $\mathrm{CCl}$-induced neurons. Additionally, unlike experimental stroke and seizure (Parent et al., 1997; Shapiro et al., 2008; Niv et al., 2012), we did not observe an increase in the formation of basal dendrites by adult-born neurons generated after $\mathrm{CCl}$.

The effect of TBI on the generation and development of adult-born neurons might also be modulated by the degree of injury. For example, a recent study by Carlson et al. (2014) reported that dendrites of immature cells born after TBI were stunted, as determined by their Dcx staining pattern. However, their model often caused direct damage to the hippocampus, and, in contrast to most other studies, decreased neurogenesis after injury. In our own work, slices in which the hippocampus was directly damaged displayed a massive increase in necrotic cell death within the dentate, which was not as obvious in our immunohistochemical experiments but was very clear in acutely prepared slices (data not shown). As we were more interested in the development of newborn granule cells in an otherwise intact hippocampus, we specifically excluded these slices, and implemented a model in which this rarely occurred. Thus, there are distinctions in the manner in which different types and severities of brain injuries affect the development of adult-born neurons.

\section{Implications for post-traumatic neurogenesis}

Due to its therapeutic implications, there has been growing research interest in promoting post-traumatic neurogenesis as an adjunctive treatment to restore cognitive function lost as a consequence of injury (Lu et al., 2003; Lu et al., 2005; Quadrato et al., 2014; Chohan et al., 2015; Xie et al., 2015). Post-traumatic neurogenesis is mainly thought to be beneficial, based on the positive association between neurogenesis and several types of learning
(Shors et al., 2001; Clelland et al., 2009; Sahay et al., 2011; Jackson et al., 2012; Nakashiba et al., 2012) and the observation that manipulations that alter neurogenesis after injury affect outcomes in animal models (Lu et al., 2005; Sun et al., 2009; Blaiss et al., 2011; Sun et al., 2015). However, as positive modulators have other effects, and the inhibition of neurogenesis is itself detrimental to learning (Shors et al., 2001; Clelland et al., 2009; Nakashiba et al., 2012), these results are difficult to interpret. If cells born after injury have aberrant functional integration, they might actually contribute to ongoing brain dysfunction, as has been suggested previously in other injury contexts (Parent and Lowenstein, 2002; Scharfman and Hen, 2007). A future analysis of the network-level effects of the neurons generated after injury will hopefully help to answer this question.

Although we did not detect physiological differences at the cell-intrinsic or overall synaptic level, the altered dendritic fields and increased proximal weighting of dendritic branch density observed in the cells born after TBI could increase the relative weighting of inputs onto these cells from the inner molecular layer (primarily mossy cell and other intrinsic hippocampal inputs) relative to those in the outer molecular layer (extrinsic lateral entorhinal afferents). As these particular input streams carry different information (Lisman, 2007), the reweighting of these inputs could have profound functional implications at the network level. Although our work does not specifically address whether the changes noted in cells born during post-traumatic neurogenesis are beneficial or maladaptive, it does demonstrate that the neurons generated after injury have both similarities and differences from those generated in healthy brains, and future work will help to further define their functional parameters and contribution to recovery, ongoing pathology, or both.-1687, USA $2 \mathrm{Har}$ vard

\section{References}

Aimone JB, Li Y, Lee SW, Clemenson GD, Deng W, Gage FH (2014) Regulation and function of adult neurogenesis: from genes to cognition. Physiol Rev 94:991-1026. CrossRef Medline

Blaiss CA, Yu TS, Zhang G, Chen J, Dimchev G, Parada LF, Powell CM, Kernie SG (2011) Temporally specified genetic ablation of neurogenesis impairs cognitive recovery after traumatic brain injury. J Neurosci 31:4906-4916. CrossRef Medline

Cameron HA, Woolley CS, McEwen BS, Gould E (1993) Differentiation of newly born neurons and glia in the dentate gyrus of the adult rat. Neuroscience 56:337-344. Medline

Carlson SW, Madathil SK, Sama DM, Gao X, Chen J, Saatman KE (2014) Conditional overexpression of insulin-like growth factor-1 enhances hippocampal neurogenesis and restores immature neuron dendritic processes after traumatic brain injury. J Neuropathol Exp Neurol 73:734-746. CrossRef Medline

Chancey JH, Adlaf EW, Sapp MC, Pugh PC, Wadiche Jl, OverstreetWadiche LS (2013) GABA depolarization is required for experience-dependent synapse unsilencing in adult-born neurons. J Neurosci 33:6614-6622. CrossRef Medline

Cheng X, Li Y, Huang Y, Feng X, Feng G, Xiong ZQ (2011) Pulse labeling and long-term tracing of newborn neurons in the adult subgranular zone. Cell Res 21:338-349. CrossRef Medline

Chirumamilla S, Sun D, Bullock MR, Colello RJ (2002) Traumatic brain injury induced cell proliferation in the adult mammalian central nervous system. J Neurotrauma 19:693-703. CrossRef Medline 
Chohan MO, Bragina O, Kazim SF, Statom G, Baazaoui N, Bragin D, Iqbal K, Nemoto E, Yonas H (2015) Enhancement of neurogenesis and memory by a neurotrophic peptide in mild to moderate traumatic brain injury. Neurosurgery 76:201-214. CrossRef Medline

Clelland CD, Choi M, Romberg C, Clemenson GD Jr, Fragniere A, Tyers P, Jessberger S, Saksida LM, Barker RA, Gage FH, Bussey TJ (2009) A functional role for adult hippocampal neurogenesis in spatial pattern separation. Science 325:210-213. CrossRef Medline

Dash PK, Mach SA, Moore AN (2001) Enhanced neurogenesis in the rodent hippocampus following traumatic brain injury. J Neurosci Res 63:313-319. Medline

Dupret D, Revest JM, Koehl M, Ichas F, De Giorgi F, Costet P, Abrous DN, Piazza PV (2008) Spatial relational memory requires hippocampal adult neurogenesis. PLoS One 3:e1959. CrossRef Medline

El-Hassar L, Milh M, Wendling F, Ferrand N, Esclapez M, Bernard C (2007) Cell domain-dependent changes in the glutamatergic and GABAergic drives during epileptogenesis in the rat CA1 region. J Physiol 578:193-211. CrossRef Medline

Espósito MS, Piatti VC, Laplagne DA, Morgenstern NA, Ferrari CC, Pitossi FJ, Schinder AF (2005) Neuronal differentiation in the adult hippocampus recapitulates embryonic development. J Neurosci 25:10074-10086. CrossRef Medline

Freund TF, Buzsáki G (1996) Interneurons of the hippocampus. Hippocampus 6:347-470. CrossRef Medline

Ge S, Goh EL, Sailor KA, Kitabatake Y, Ming GL, Song H (2006) GABA regulates synaptic integration of newly generated neurons in the adult brain. Nature 439:589-593. CrossRef Medline

Gould E, Beylin A, Tanapat P, Reeves A, Shors TJ (1999) Learning enhances adult neurogenesis in the hippocampal formation. Nat Neurosci 2:260-265. CrossRef Medline

Gupta A, Elgammal FS, Proddutur A, Shah S, Santhakumar V (2012) Decrease in tonic inhibition contributes to increase in dentate semilunar granule cell excitability after brain injury. J Neurosci 32:2523-2537. CrossRef Medline

Hunt RF, Dinday MT, Hindle-Katel W, Baraban SC (2012) LIS1 deficiency promotes dysfunctional synaptic integration of granule cells generated in the developing and adult dentate gyrus. J Neurosci 32:12862-12875. CrossRef Medline

Jackson J, Chugh D, Nilsson P, Wood J, Carlström K, Lindvall O, Ekdahl CT (2012) Altered synaptic properties during integration of adult-born hippocampal neurons following a seizure insult. PLoS One 7:e35557. CrossRef Medline

Jessberger S, Zhao C, Toni N, Clemenson GD Jr, Li Y, Gage FH (2007) Seizure-associated, aberrant neurogenesis in adult rats characterized with retrovirus-mediated cell labeling. J Neurosci 27:9400-9407. CrossRef Medline

Jin K, Minami M, Lan JQ, Mao XO, Batteur S, Simon RP, Greenberg DA (2001) Neurogenesis in dentate subgranular zone and rostral subventricular zone after focal cerebral ischemia in the rat. Proc Natl Acad Sci U S A 98:4710-4715. CrossRef Medline

Kempermann G, Kuhn HG, Gage FH (1997) More hippocampal neurons in adult mice living in an enriched environment. Nature 386:493-495. CrossRef Medline

Kernie SG, Erwin TM, Parada LF (2001) Brain remodeling due to neuronal and astrocytic proliferation after controlled cortical injury in mice. J Neurosci Res 66:317-326. Medline

Lisman JE (2007) Role of the dual entorhinal inputs to hippocampus: a hypothesis based on cue/action (non-self/self) couplets. Prog Brain Res 163:615-625. CrossRef Medline

Liu J, Solway K, Messing RO, Sharp FR (1998) Increased neurogenesis in the dentate gyrus after transient global ischemia in gerbils. $J$ Neurosci 18:7768-7778. Medline

Lu D, Mahmood A, Zhang R, Li Y, Copp M (2003) Upregulation of neurogenesis and reduction in functional deficits following administration of DETA/NONOate, a nitric oxide donor, after traumatic brain injury in rats. J Neurosurg 99:351-361. CrossRef Medline

Lu D, Mahmood A, Qu C, Goussev A, Schallert T, Chopp M (2005) Erythropoietin enhances neurogenesis and restores spatial mem- ory in rats after traumatic brain injury. J Neurotrauma 22:10111017. CrossRef Medline

Madisen L, Zwingman TA, Sunkin SM, Oh SW, Zariwala HA, Gu H, $\mathrm{Ng}$ LL, Palmiter RD, Hawrylycz MJ, Jones AR, Lein ES, Zeng H (2010) A robust and high-throughput Cre reporting and characterization system for the whole mouse brain. Nat Neurosci 13:133140. CrossRef Medline

Nakashiba T, Cushman JD, Pelkey KA, Renaudineau S, Buhl DL, McHugh TJ, Rodriguez Barrera V, Chittajallu R, Iwamoto KS, McBain CJ, Fanselow MS, Tonegawa S (2012) Young dentate granule cells mediate pattern separation, whereas old granule cells facilitate pattern completion. Cell 149:188-201. CrossRef Medline

Niv F, Keiner S, Krishna, Witte OW, Lie DC, Redecker C (2012) Aberrant neurogenesis after stroke: a retroviral cell labeling study. Stroke 43:2468-2475. CrossRef Medline

Overstreet LS, Hentges ST, Bumaschny VF, de Souza FS, Smart JL, Santangelo AM, Low MJ, Westbrook GL, Rubinstein M (2004) A transgenic marker for newly born granule cells in dentate gyrus. $J$ Neurosci 24:3251-3259. CrossRef Medline

Overstreet Wadiche L, Bromberg DA, Bensen AL, Westbrook GL (2005) GABAergic signaling to newborn neurons in dentate gyrus. J Neurophysiol 94:4528-4532. CrossRef Medline

Overstreet-Wadiche LS, Bromberg DA, Bensen AL, Westbrook GL (2006) Seizures accelerate functional integration of adult-generated granule cells. J Neurosci 26:4095-4103. CrossRef Medline

Parent JM, Lowenstein DH (2002) Seizure-induced neurogenesis: are more new neurons good for an adult brain? Prog Brain Res 135:121-131. CrossRef Medline

Parent JM, Yu TW, Leibowitz RT, Geschwind DH, Sloviter RS, Lowenstein DH (1997) Dentate granule cell neurogenesis is increased by seizures and contributes to aberrant network reorganization in the adult rat hippocampus. J Neurosci 17:3727-3738. Medline

Perederiy JV, Luikart BW, Washburn EK, Schnell E, Westbrook GL (2013) Neural injury alters proliferation and integration of adultgenerated neurons in the dentate gyrus. J Neurosci 33:4754-4767. CrossRef Medline

Pugh P, Adlaf E, Zhao CS, Markwardt S, Gavin C, Wadiche J, Overstreet-Wadiche $L$ (2011) Enhanced integration of newborn neurons after neonatal insults. Front Neurosci 5:45. CrossRef Medline

Quadrato G, Elnaggar MY, Di Giovanni S (2014) Adult neurogenesis in brain repair: cellular plasticity vs. cellular replacement. Front Neurosci 8:17. CrossRef Medline

Rice AC, Khaldi A, Harvey HB, Salman NJ, White F, Fillmore H, Bullock MR (2003) Proliferation and neuronal differentiation of mitotically active cells following traumatic brain injury. Exp Neurol 183:406-417. Medline

Sahay A, Scobie KN, Hill AS, O'Carroll CM, Kheirbek MA, Burghardt NS, Fenton AA, Dranovsky A, Hen R (2011) Increasing adult hippocampal neurogenesis is sufficient to improve pattern separation. Nature 472:466-470. CrossRef Medline

Santhakumar V, Ratzliff AD, Jeng J, Toth Z, Soltesz I (2001) Longterm hyperexcitability in the hippocampus after experimental head trauma. Ann Neurol 50:708-717. Medline

Santhakumar V, Bender R, Frotscher M, Ross ST, Hollrigel GS, Toth Z, Soltesz I (2000) Granule cell hyperexcitability in the early posttraumatic rat dentate gyrus: the "irritable mossy cell" hypothesis. J Physiol 524:117-134. Medline

Scharfman HE, Hen R (2007) Neuroscience. Is more neurogenesis always better? Science 315:336-338. CrossRef Medline

Scharfman HE, Goodman JH, Sollas AL (2000) Granule-like neurons at the hilar/CA3 border after status epilepticus and their synchrony with area CA3 pyramidal cells: functional implications of seizureinduced neurogenesis. J Neurosci 20:6144-6158. Medline

Shapiro LA, Ribak CE, Jessberger S (2008) Structural changes for adult-born dentate granule cells after status epilepticus. Epilepsia 49 [Suppl5]:13-18. CrossRef Medline

Shors TJ, Miesegaes G, Beylin A, Zhao M, Rydel T, Gould E (2001) Neurogenesis in the adult is involved in the formation of trace memories. Nature 410:372-376. CrossRef Medline 
Spalding KL, Bergmann O, Alkass K, Bernard S, Salehpour M, Huttner HB, Boström E, Westerlund I, Vial C, Buchholz BA, Possnert G, Mash DC, Druid H, Frisén J (2013) Dynamics of hippocampal neurogenesis in adult humans. Cell 153:1219-1227. CrossRef Medline

Sun D, Daniels TE, Rolfe A, Waters M, Hamm RJ (2015) Inhibition of injury-induced cell proliferation in the dentate gyrus of the hippocampus impairs spontaneous cognitive recovery after traumatic brain injury. J Neurotrauma 32:495-505. CrossRef

Sun D, McGinn MJ, Zhou Z, Harvey HB, Bullock MR, Colello RJ (2007) Anatomical integration of newly generated dentate granule neurons following traumatic brain injury in adult rats and its association to cognitive recovery. Exp Neurol 204:264-272. CrossRef Medline

Sun D, Bullock MR, McGinn MJ, Zhou Z, Altememi N, Hagood S, Hamm R, Colello RJ (2009) Basic fibroblast growth factorenhanced neurogenesis contributes to cognitive recovery in rats following traumatic brain injury. Exp Neurol 216:56-65. CrossRef Medline

van Praag H, Christie BR, Sejnowski TJ, Gage FH (1999) Running enhances neurogenesis, learning, and long-term potentiation in mice. Proc Natl Acad Sci U S A 96:13427-13431. Medline

van Praag H, Shubert T, Zhao C, Gage FH (2005) Exercise enhances learning and hippocampal neurogenesis in aged mice. J Neurosci 25:8680-8685. CrossRef Medline

van Praag H, Schinder AF, Christie BR, Toni N, Palmer TD, Gage FH (2002) Functional neurogenesis in the adult hippocampus. Nature 415:1030-1034. CrossRef Medline
Varela-Nallar L, Rojas-Abalos M, Abbott AC, Moya EA, Iturriaga R, Inestrosa NC (2014) Chronic hypoxia induces the activation of the Wnt/ $\beta$-catenin signaling pathway and stimulates hippocampal neurogenesis in wild-type and APPswe-PS1 1 E9 transgenic mice in vivo. Front Cell Neurosci 8:17. CrossRef Medline

Villasana LE, Westbrook GL, Schnell E (2014) Neurologic impairment following closed head injury predicts post-traumatic neurogenesis. Exp Neurol 261:156-162. CrossRef Medline

Xie C, Cong D, Wang X, Wang Y, Liang H, Zhang X, Huang Q (2015) The effect of simvastatin treatment on proliferation and differentiation of neural stem cells after traumatic brain injury. Brain Res 1602:1-8. CrossRef Medline

Yu TS, Zhang G, Liebl DJ, Kernie SG (2008) Traumatic brain injuryinduced hippocampal neurogenesis requires activation of early nestin-expressing progenitors. J Neurosci 28:12901-12912. CrossRef Medline

Zhao C, Deng W, Gage FH (2008) Mechanisms and functional implications of adult neurogenesis. Cell 132:645-660. CrossRef Medline

Zhao C, Teng EM, Summers RG Jr, Ming GL, Gage FH (2006) Distinct morphological stages of dentate granule neuron maturation in the adult mouse hippocampus. J Neurosci 26:3-11. CrossRef Medline[Mismatch]

Zhu LL, Zhao T, Li HS, Zhao H, Wu LY, Ding AS, Fan WH, Fan M (2005) Neurogenesis in the adult rat brain after intermittent hypoxia. Brain Res 1055:1-6. CrossRef Medline 